\title{
Un répertoire des accidents radiologiques 1945-1985*
}

\author{
Alexandre RODRIGUES DE OLIVEIRA** \\ (Manuscrit reçu le 19 décembre 1986)
}

\begin{abstract}
RÉSUMÉ
Ce bilan est un répertoire des accidents radiologiques les plus importants survenus pendant la période 1945-1985 et qui sont présentés d'une façon sommaire. La plupart des informations incluses ont été obtenues dans la bibliographie scientifique. Ce document est principalement destiné aux professionnels qui travaillent dans le domaine de la sûreté des installations nucléaires et radioactives.
\end{abstract}

\section{ABSTRACT}

Approximately 180 radiation accidents which occurred in the world during the period 1945-1985 are summarized. The organisation and structuring of this document rests on the necessity of the availability of a database specifically oriented toward scientists interested in studying the different radiation accidents reported. Most accidents have been described in the scientific literature.

\section{PRÉAMBULE}

Les données incluses dans ce document ont fait l'objet d'une recherche ample et minutieuse de la bibliographie concernant les accidents radiologiques survenus pendant la période 1945-1985. Une partie importante des informations considérées dans ce travail a été obtenue grâce aux rapports établis entre l'auteur et des spécialistes qui, de quelque façon, ont participé au suivi des victimes de ces accidents ou à l'analyse de ceux-ci.

II faut dire que de nombreux accidents n'ont pas pu être répertoriés dans ce document, compte tenu du fait qu'ils n'ont pas été publiés dans des revues spécialisées ou sous une autre forme de divulgation. Cette lacune devrait être comblée pour ceux qui portent un intérêt actif à ce chapitre de l'énergie nucléaire.

* Document élaboré lors d'un stage à l'Institut de protection et de sûreté nucléaire (IPSN) du Commissariat à l'énergie atomique, sous l'égide de l'Agence internationale de l'énergie atomique (AIEA).

** Adresse actuelle: Instituto nuclebras de Seguridade Social, rua General Polidoro 316, Sala 4102, Botafogo, CEP 22280 Rio de Janeiro, Brésil.

RADIOPROTECTION, VOL. 22 - 0033-8451/1987/89/\$ 5.00 Cédim. 


\section{INTRODUCTION}

\section{Aspects historiques}

Les accidents radiologiques sont contemporains de la découverte des rayons X par Roentgen, en 1885, et des substances radioactives par Becquerel, en 1896. Dès 1896, certains auteurs ont publié des comptes rendus sur les effets de l'irradiation sur l'homme, particulièrement sur la peau. Sans tenir compte de l'ordre chronologique, mentionnons d'abord O. Leppin (1896), qui exposa sa propre main aux rayons cathodiques d'une ampoule rudimentaire à rayons $X$. II a décrit les résultats de cette expérience dans la revue "Deutsche medizinische Wochenschrift", 1986, vol. 28, page 454. Cette même année, Daniel décrit les effets dépilatoires des rayons $X$ et publie ses constatations dans la revue "Medical record".

A cette même époque, il publie encore un autre travail, désormais classique, sur les effets et les risques des rayons X. En Angleterre, Stevens (1896) décrit également, brièvement, les effets nuisibles des rayons $X$ sur la peau dans le "British medical journal". En 1909, Wolbach a décrit les caractéristiques histopathologiques de la dermatite chronique causée par une application suivie de rayons $X$ et l'incidence de carcinome épidermique chez les professionnels qui s'exposaient à cette radiation. La même année, Porter analyse et traite chirurgicalement 47 cas de lésions provoquées par les rayons $X$. Pendant les décades 20 et 30 , on note que les ouvrages sur les accidents se font plus rares et les quelques travaux divulgués se rapportent invariablement à la description des lésions causées par les rayons X, ainsi qu'aux effets découlant des brûlures par le radium, nous informant indirectement sur l'importance que ces éléments ont eu pendant cette période.

Depuis 1942, date de la première excursion critique aux laboratoires de I'Université de Chicago, et jusqu'en 1945, lorsqu'eut lieu l'explosion expérimentale à Alamogordo, Nouveau Mexique, du premier engin nucléaire, on ne possède pas d'informations officielles sur les accidents nucléaires survenus dans les installations nucléaires américaines. Datés de 1948, apparaissent alors les premiers rapports sur les accidents connus, tels ceux de Los Alamos I (1945) et Los Alamos II (1946), et qui décrivent les conditions dans lesquelles ceux-ci se sont déroulés, respectivement dans les laboratoires de Omega Site et de Parajito. En 1952, dans une étude désormais classique et de lecture obligatoire, Hempelmann, Lisco et Hoffmann décrivent les signes et les symptômes caractéristiques du syndrome d'irradiation aiguë, en se basant sur l'évolution du cas de 9 parmi les 10 victimes des accidents en question. En 1949, Knowlton et al. décrivent les effets des rayonnements bêta sur la peau de personnes ayant manipulé intentionnellement des produits de fission sur le site d'essais d'Eniwetok (tests atomiques). Un des aspects marquants de cette période est constitué par le fait que les accidents survenus concernaient, en général, des techniciens et des scientifiques attachés aux programmes de développement de la technologie et de la production d'engins nucléaires aux Etats-Unis. La bibliographie existante reflète les rigueurs de la censure relative aux activités stratégiques. Outre leur caractère fragmentaire, ces publications n'offrent pas au lecteur les détails insdispensables à une parfaite compréhension de la génèse des accidents nucléaires. Le plus souvent, ils se limitent à décrire les 
effets biologiques du rayonnement gamma et des neutrons qui découlent des accidents de criticité. Cette absence d'informations ne signifiait, en aucune manière, un manque d'intérêt des chercheurs pour la matière, bien au contraire. Le fait qu'ils soient empêchés de publier leurs découvertes et leurs conclusions, était compensé, largement, par les efforts qu'ils faisaient pour extraire de leurs études le plus grand nombre possible d'informations capables d'être utilisées à brève échéance. II est indéniable que l'on a appris beaucoup au cours de cette période pendant laquelle les bases de notre actuelle connaissance sur les effets nuisibles des radiations ionisantes furent établies. Cela sans parler de l'importante impulsion donnée à la science de la radioprotection et à la "cristallisation" du concept de sécurité dans les installations nucléaires.

En 1955, lors de la conférence internationale des Nations Unies pour l'utilisation pacifique de l'atome, s'est ouverte une ère nouvelle. Des accidents jusqu'alors inconnus de la communauté scientifique furent divulgués (Argonne, 1952; Russie, 1953), cette divulgation précédant la publication, au cours des années suivantes, d'études plus détaillées sur les deux accidents survenus à Los Alamos, aussi bien qu'un certain nombre de comptes rendus et d'articles relatifs aux retombées sur les lles Marshall, aux accidents de Los Alamos III, Oak Ridge et Vinča (1958). Dans les années 60, quelques accidents survenus dans les installations nucléaires sont relatés tels que Idaho Falls (1961), Hanford (1962), Rhode Island (1964) et Mol (1965) qui ont été largement étudiés et commentés dans les publications spécialisées.

Par contre, les événements accidentels causés par les irradiateurs de cobalt, les sources scellées de césium et d'iridium, les rayons $\mathrm{X}$ appliqués à la recherche, à l'industrie ou à la médecine sont à l'origine de nombreuses publications. II faudrait y ajouter d'innombrables références bibliographiques sur les accidents de contamination interne dus principalement à l'américium et au plutonium. Cette abondance de publications sur les accidents qui se sont produits dans les installations nucléaires et dans les établissements où l'on utilise des sources scellées ou non scellées s'est maintenue durant les années 70 et, semble-t-il, ne s'est pas modifiée durant la période 1981-1985. La bibliographie actuelle offre surtout des articles et des ouvrages sur des incidents ou des accidents liés à des sources scellées d'iridium et à des équipements de rayons $X$ d'application industrielle ou scientifique.

\section{Difficultés rencontrées pour rassembler les données existantes}

Le chercheur qui souhaite recueillir des données sur les accidents nucléaires survenus dans le passé rencontrera certainement de sérieuses difficultés pour trouver les nombreuses sources bibliographiques existantes, principalement en raison de la multiplicité des documents relatifs à ce sujet. L'accès rapide à ces sources se heurtera à un obstacle supplémentaire, car le sujet est traité, dans ses différents aspects, dans des articles de revues s'adressant au grand public ou bien dans des périodiques dont la diffusion est restreinte à la communauté médicale.

Dans ce large spectre de sources de références, doivent être incluses les publications qui traitent de thèmes comme la sécurité du travail dans les 
installations nucléaires ou de la radioprotection, telles que Health physics, Nuclear safety et Radioprotection, ainsi que l'hebdomadaire Nucleonics week, les actes des congrès et des réunions d'organisations internationales: Organisation mondiale de la santé (OMS), Organisation internationale du travail (OIT), Agence internationale de l'énergie atomique (AIEA), Association internationale de radioprotection (IRPA) et l'ONU sans oublier les comptes rendus détaillés publiés par les institutions qui ont eu la tâche difficile de "gérer" l'accident et ses conséquences.

Cette diversité de sources d'information, dispersées entre des institutions de caractères bien distincts, contraint l'intéressé à un véritable effort pour les retrouver. S'agissant d'accidents radiologiques, il est permis d'imaginer que le chercheur puisse avoir intérêt à la récupération immédiate de la source en question, ne pouvant attendre que soient menées à terme les recherches qui peuvent durer des heures et même des semaines dans l'hypothèse où le document souhaité vient de l'étranger, et que soient obtenues les données nécessaires. En outre, dans le cas d'accident radiologique, il est classique de procéder à une comparaison entre les différents aspects de ceux-ci et des situations semblables survenues dans le passé. Cette comparaison ne peut-être faite que moyennant l'obtention des documents relatifs à l'événement survenu antérieurement.

Le nombre de travaux publiés sur ce sujet est considérable. Apparemment, les documents parus en la matière ont été plus nombreux dans les périodes qui ont suivi les accidents les plus importants de l'âge nucléaire, plus précisément entre les années 40 et 60 .

Pendant les années 40 et au début des années 50 , de nombreux rapports de caractère confidentiel traitaient d'accidents survenus dans des installations du cycle de production d'armes nucléaires aux USA.

II convient de signaler qu'une grande partie des documents publiés à cette époque sur les accidents nucléaires provenaient de ce pays, les travaux provenant des pays de l'Est étant rares. A partir du moment où furent introduits des mécanismes de sécurité plus efficaces, on a pu observer une réduction significative du nombre de cas dans les installations nucléaires dites de production, alors que survenait cependant un accroissement substantiel d'accidents relatifs à l'emploi des sources du type irradiateurs d'iridium et de cobalt, appareils à rayons $X$ et autres engins générateurs de rayonnement.

\section{Analyse globale d'un accident nucléaire ou radiologique}

L'analyse globale d'un accident doit se baser sur d'innombrables aspects. Cependant, un élément doit toujours être mis en valeur par les professionnels qui travaillent dans le domaine de la sécurité de l'installation: l'élément causal peut être de nature humaine dans certains accidents ou peut trouver son origine dans un défaut des installations, ou encore, dans bien des cas, peut procéder à la fois de ces deux types de cause.

Dans le domaine des activités nucléaires, outre ce qui précède, doivent être recherchées d'autres données qui auront un rôle important dans l'analyse de l'accident. 
Ainsi, il est fondamental d'ébaucher des hypothèses sur la genèse de l'événement et sur l'opération qui était en cours au moment de l'accident, en déterminant, chaque fois que cela est possible, les positions dans lesquelles se trouvaient les victimes par rapport à l'agent qui a causé l'accident, le type de matériel nucléaire ou l'équipement générateur de rayonnement, l'activité de la source, le nombre des victimes et la gravité des expositions. Ces informations, lorsqu'elles sont correctement recueillies, permettent la reconstitution de l'accident, l'estimation avec une bonne marge de certitude des doses reçues par les victimes et leur distribution dans le corps (isodoses). Cependant, il est souhaitable de confronter ces données avec les informations obtenues lors de l'analyse d'accidents survenus dans le passé, procédé qui permettra aux équipes chargées de contrôler l'accident d'adopter les mesures permettant d'éviter sa répétition et de déterminer les précautions relatives au traitement des accidentés.

\section{Bilan général des accidents radiologiques}

Ce document rassemble les principaux accidents survenus pendant la période 1945-1985. On entend par accidents importants ceux qui ont provoqué l'exposition à des doses élevées, ayant obligé les irradiés à se soumettre à un traitement médical.

Nous présentons un résumé des principaux accidents survenus dans les dernières quarante années, sous la forme de tableaux où figurent quelques types d'accidents susceptibles de se produire lorsqu'on manipule des matériaux nucléaires. Afin d'orienter le lecteur, nous avons pensé qu'il serait souhaitable d'opérer une distinction entre les accidents de criticité (tableau I) et ceux où il s'est produit une irradiation externe due à d'autres sources que celles provenant d'installations critiques (tableau III). De plus, nous avons introduit quelques informations importantes sur l'accident survenu aux lles Marshall, telles que le nombre des victimes, les doses et les effets observés sur la population de l'archipel (tableau II). Les documents concernant chaque événement mentionné sont cités dans la colonne "références" sous forme alphanumérique; les principales sources consultées sont soulignées. Pour les connaître, il suffit de se reporter à la bibliographie.

Pour les tableaux I, II et III:

- les astériques signifient que le patient a fait l'objet d'une intervention chirurgicale;

- "globale" indique l'irradiation de tout le corps;

- "Iocalisée" signifie l'exposition d'une partie déterminée du corps, indiquée entre parenthèses;

- les malades du sexe féminin sont représentés par la lettre " $f$ ".

Le lecteur notera que les unités de mesure des différentes grandeurs employées pour indiquer les expositions, doses absorbées, doses équivalentes et activités, sont exprimées soit dans le système international (SI), soit 
dans des systèmes distincts; ceci est dû au fait que ces unités ont été indiquées par ces différents symboles dans les documents originaux. Le tableau IV, enfin, récapitule l'historique des accidents nucléaires survenus pendant la période 1945-1985.

\section{REMERCIEMENTS}

Je tiens à remercier les Drs. Roger GONGORA de l'Institut Curie et Jean-Claude NÉNOT du Département de protection sanitaire de l'IPSN, pour l'appui reçu pendant la réalisation de ce travail ainsi que pour leur encouragement constant.

Je tiens également à remercier les bibliothécaires et documentalistes des services de documentation du Département de protection sanitaire et de l'Institut Curie, pour leur travail diligent et infatigable de recherche des publications indispensables à l'élaboration de ce document.

Mes sincères remerciements vont à tous ceux qui ont eu la bonne volonté de me faire parvenir des publications et rapports concernant les accidents radiologiques considérés dans notre bilan général:

Dr. Shirley A. FRY, Center for epidemiological research, Medical and health sciences division, Oak Ridge associated universities, USA.

Drs. Robert A. CONARD, Edward T. LESSARD et William H. ADAMS, Marshall Islands medical program, Brookhaven national laboratory.

Dr. George L. VOELZ, assistant division leader program, Los Alamos national laboratory, USA.

Dr. Niel WALD, Department of radiation health, University of Pittsburg, USA.

Dr. Juan Carlos GIMENEZ, División médico radiosanitaria, Comisión nacional de energia atomica, Argentine.

Dr. Rolf LINGJAERDE, Information department, Institute for energy technology, Norvège.

Drs. Carlos Eduardo de ALMEIDA et Paulo CUNHA, Instituto de radioproteção e dosimetria, Comissão nacional de energia nuclear, Brésil.

Dr. David LLOYD, National radiological protection board, Grande-Bretagne.

\section{BIBLIOGRAPHIE}

A1. Accidental exposure involving $X$-ray spectrometer unit. Serious accidents, United States Atomic Energy Commission, Issue 338, December 6, 1974.

A2. Accidental radiation excursion at the $Y-12$ plant June 16, 1958. United States Atomic Energy Commission. Report Y-1234, 1958.

A3. ADAMS W.H., HARPER J.A., RITTMASTER R.S., HEOTIS P.M., SCOTT W.A. Medical status of Marshallese accidentally exposed to 1954 Bravo fallout radiation: January 1980 - December 1982. BNL-51761, 1984.

A4. ADAMS W.H. et al. Pituitary tumors following fallout radiation exposure. JAMA, 1984, 252 (5), 664-666.

A5. AEBERSOLD P., HEMPELMAN L.H., SLOTIN L. Report of accident of August 21 , 1945, at Omega Site. LAMS-120, 1948.

A6. ALLEN W.R. Ignorance, experimentation and tragedy: radiation injury to the hand. J. Kansas Med. Soc., 1966 (Sept.), 447-453. 
A7. ANDREWS G.A., SITTERSON B.W., KRETCHMAR A.L. Accidental radiation excursion at the Oak Ridge $Y-12$ Plant. 4. Preliminary report on clinical and laboratory effects in the irradiated employees. Health Phys., 1959, 2, 134-138.

A8. ANDREWS G.A., SITTERSON B.W., KRETCHMAR A.L., BRUCER M. Criticality accident at the $Y-12$ plant. In : Diagnosis and treatment of acute radiation injury, Geneva, 17-20 October, 1960. Genève: OMS, 1961, 27-98.

A9. ANDREWS G.A. Criticality accidents in Vinca, Yugoslavia, and Oak Ridge, Tennessee. Comparison of radiation injuries and results of therapy. JAMA, 1962. 179, $191-197$.

A10. ANDREWS G.A. Mexican ${ }^{60}$ Co radiation accident. Isot. Radiat. Technol., 1963$1964,1,200-201$.

A11. ANDREWS G.A., AUXIER J.A., LUSHBAUGH C.C. The importance of dosimetry to the medical management of persons accidentally exposed to high levels of radiation. In: Personnel dosimetry for radiation accidents, Vienna, 8-12 March 1965. Vienne: AIEA, 1965, 3-16.

A12. ANDREWS G.A., HÜBNER K.F., FRY S.A. Report of 21-year medical follow-up of survivors of the Oak Ridge $\mathrm{Y}-12$ accident. In: The medical basis for radiation accident preparedness (Hübner K.F., Fry S.A., Eds.) New York: Elsevier, 1980, 59-79.

A13. ANNAMALAI M., IYER R.S., PANICKER T.M.R. Radiation injury from acute exposure to an iridium-192 source: case history. Health Phys., 1978, 35, 387-389.

A14. ATOMIC ENERGY OFFICE. Accident at Windscale $N^{\circ} 1$ pile on 10th October, 1957. London: HMSO, 1957 (Cmnd. 302).

A15. AUXIER J.A. Dosimetric considerations in criticality exposures. In: Diagnosis and treatment of acute radiation injury, Geneva, 17-20 October 1960. Genève: OMS, $1961,141-150$.

A16. AUXIER J.A. Nuclear accident at Wood River Junction. Nucl. Safety, 1965, 6 (3) 298-300.

A17. AUXIER J.A. Dosimetry and exposures in nuclear accidents. Nucl. Safety, 1967, 8 (4) $382-385$

A18. AUXIER J.A., BERGER C.D., DUNNING D.E. Americium-241 distribution and excretion in humans and the effects of chelation. In: Abstracts of papers presented at the 29. annual meeting of the Health physics society, New Orleans, Louisiana, June 3-8, 1984, P/272. Health Phys., 1984, 47 (1) 186-187.

B1. BAILEY E.D., WUKASCH M.D. A case of felonious use of radioactive materials. In: 4. International IRPA congress, Paris, 24-30 April 1977, 3, 987-990.

B2. BALNER $\mathrm{H}$. Bone marrow transplantation and other treatment after radiation injury. EUR-5884, 1977.

B3. BARLOTTA F.M. The New Jersey radiation accidents of 1974 and 1977. In: The medical basis for radiation accident preparedness (Hübner K.F., Fry S.A., Eds). New York: Elsevier, 1980, 151-160.

B4. BARANOV A.E. et al. A case of acute radiation sickness which developed after general uniform gamma irradiation $\left({ }^{60} \mathrm{Co}\right)$ (en russe). Medits. Radiol., 1977, 18 (8) $48-55$.

B5. BARON J.M., YACHIN S., POLCYN R., FITCH F.W., STURNER W. Accidental radiogold $\left({ }^{198} \mathrm{Au}\right)$ liver scan overdose with fatal outcome. In: Handling of radiation accidents, Vienna, 19-23 May 1969. Vienne: AIEA, 1969, 399-414.

VOL. $22-\mathrm{N}^{\circ} 2$ 
B6. BASSON J.K., HANEKOM A.P., COETZEE F.C. et al. Health physics evaluation of an acute over-exposure to a radiography source. In: Radiation protection: a systematic approach to safety, 5 . Congress of the IRPA, Jerusalem, 1980, Oxford: Pergamon press, 1980, 64-68.

B7. BASSON J.K., HANEKOM A.P., COETZEE F.C., LLOYD D.C. Health physics evaluation of an accident involving acute overexposure to a radiography source. Atomic Energy Board, Pelindaba, Pretoria RSA, PEL-279, 1981.

B8. BAVERSTOCK K.F., ASH P.J.N.D. A review of radiation accidents involving wholebody exposure and the relevance to the LD 50/60 for man. Brit. J. Radiol., 1983, $56,837-849$

B9. BECQUEREL H., CURIE P. Action physiologique des rayons du radium. C.R. Acad. Sci., 1901, 132, 1289-1291.

B10. BENDER M.A., GOOCH P.C. Persistent chromosome aberrations in irradiated human subjects. Radiat. Res., 1962, 16, 44-53.

B11. BENDER M.A., GOOCH P.C. Somatic chromosome aberrations induced by human whole-body irradiation: the "Recuplex" criticality accident. Radiat. Res., $1966,29,568-582$.

B12. BENINSON D., PLACER A., VANDER ELST E. Estudio de un caso de irradiacion humana accidental. In: Handling of radiation accidents, 19-23 May 1969. Vienne: AIEA, 1969, 415-429.

B13. BENINSON D., PLACER A., VANDER ELST E. Etude d'un cas d'irradiation humaine accidentelle. Radioprotection, 1971, 6 (4) 243-253.

B14. BERTEIG L., FLATBY J. The radiation accident at Institute for energy technology, September 1982. 2. Some technical considerations. SIS Report 1983, 7, 1983.

B15. BHUSHAN V. Large radiation exposure. In: 3 . International congress of IRPA. Washington, 1973. CONF-730907, 1974, 769-772.

B16. BLISS S.P. Medical aspects of an accidental exposure to Van de Graaf generator. In: 1. Colloque international sur la protection auprès des grands accélérateurs, 18-20 janvier 1962. Paris: Presses universitaires de France, 1962, 35-36.

B17. BOND V.P., CONARD R.A., ROBERTSON J.S., WEDEN E.A., Jr. Medical examination of Rongelap people six months after exposure to fallout, Operation castle addendum report 4.1A, WT-937, 1955.

B18. BOULENGER R., PARMENTIER N., LE GÔ R. et al. Description et analyse de l'accident de criticité survenu au réacteur Vénus à Mol le 30 décembre 1965. In: Les irradiations accidentelles en milieu de travail, Nice, 26-29 avril 1966. EUR3666, 1967, 357-391.

B19. BREWEN J.G., PRESTON R.J., LITTLEFIELD L.G. Radiation-induced human chromosome aberration yields following an accidental whole-body exposure to ${ }^{60} \mathrm{Co}$ $\gamma$-rays. Radiat. Res., 1972, 49, 647-656.

B20. BROWN J.B., FRYER M.P. Report of surgical repair in the first group of atomic radiation injuries. Surg. Ginecol. Obstet., 1956, 103 (1) 1-4, 1956.

B21. BROWN J.B., FRYER M.P. High energy electron injury from accelerator machines (cathode rays). Ann. Surgery, 1965, 162, 426-437.

B22. BROWN J.K., MCNEILL J.R. Biological dosimetry in an industrial radiography accident. Health Phys., 1971, 21, 519-522.

B23. BRUCER M. The acute radiation syndrome: a medical report on the Y-12 accident, June 16, 1958. US Atomic Energy Commission, ORINS-25, 1959. 
B24. BUCHANAN J.R. SL-1 accident final report. Nucl. Safety, 1963, 4 (3) 83-86.

B25. BUTLER M.J., ORCHARD P.G. Over-exposure of a service engineer in a hospital. Radiol. Prot. Bull., 1976, 17, 36-38.

C1. CALLIHAN D., THOMAS J.T. Accidental radiation excursion at the Oak Ridge Y12 Plant. 1. Description, physics of the accident. Health Phys., 1959, 1, 363-372.

C2. CALLIHAN D. Accidental nuclear excursion in Recuplex operation at Hanford in April 1962. Nucl. Safety, 1963, 4 (4) 136-143.

C3. CARTER R.W., KARP H.C. Investigation of a diagnostic $x$-ray radiation accident. Health Phys., 1980, 39, 231-235.

C4. CHONÉ B., SCHNEIDER G.J., FAHRENTZ D. 192 Iridium-Kontakbestrahlung und Folgeerscheinungen. Strahlentherapie, 1970, 140 (1) 113-122.

C5. COHEN N., SASSO T.L., WRENN McD. Metabolism of americium 241 in man; an unusual case of internal contamination of a child and his father. Science, 1979, 206 (4414) 64-66.

C6. COHN S.H. Metabolism of fission products in man: Marshallese experience. In: Diagnosis and treatment of radioactive poisoning, Vienna, 15-18 October 1962. Vienne: AIEA, 1963, 235-251.

C7. COLLINS V.P., GAULDEN M.E. A case of child abuse by radiation exposure. In: The medical basis for radiation accident preparedness (Hübner K.F., Fry S.A., Eds.). New York: Elsevier, 1980, 197-203.

C8. COMISIÓN NACIONAL DE ENERGIA ATOMICA (Argentine). Communication personnelle.

C9. COMISIÓN NACIONAL DE SEGURIDAD NUCLEAR Y SALVAGUARDIAS (Mexico). Accidente por contaminación con cobalto-60, México, 1984. CNSNSIT-001, 1985.

C10. CONARD R.A. et al. Medical survey of Marshallese two years after exposure to fallout radiation. BNL-412, 1956.

C11. CONARD R.A. et al. Medical survey of Rongelap and Utirik people three years after exposure to radioactive fallout. BNL-501, 1958.

C12. CONARD R.A. et al. Medical survey of Rongelap people, four years after exposure to fallout. BNL-534, 1959.

C13. CONARD R.A. et al. Medical survey of Rongelap people five and six years after exposure to fallout. BNL-609, 1960.

C14. CONARD R.A. Medical survey of Marshallese people five years after exposure to fallout radiation. Int. J. Radiat. Biol., 1960, suppl. 1, 269-281.

C15. CONARD R.A. The biological hazards of a fallout field. In: Radioactivity in man, (Meneely G.R., Ed.). Springfield: C. Thomas, 1961, 249-265.

C16. CONARD R.A. et al. Medical survey of Rongelap people seven years after exposure to fallout. BNL-727, 1962.

C17. CONARD R.A. et al. Medical survey of Rongelap people eight years after exposure to fallout. BNL-780, 1963.

C18. CONARD R.A. et al. Medical survey of the people of Rongelap and Utirik islands nine and ten years after exposure to fallout radiation. BNL-908, 1965.

C19. CONARD R.A., HICKING A. Medical findings in Marshallese people exposed to fallout radiation: results from a ten-year study. JAMA, 1965, 192, 457-459.

C20. CONARD R.A., RALL J.E., SUTOW W.W. Thyroid nodules as a late sequela of radioactive fallout in a Marshall Islands population exposed in 1954. New Engl. J. Med., 1966, 274, 1392-1399. 


\section{A. RODRIGUES DE OLIVEIRA}

C21. CONARD R.A. et al. Medical survey of the people of Rongelap and Utirik islands eleven and twelve years after exposure to fallout radiation. BNL-50029, 1967.

C22. CONARD R.A., SUTOW W.W., COLCOCK B.P., DOBYNS B.M., PAGLIA D.E. Thyroid nodules as a late effect of exposure to fallout. In: Radiation-induced cancer, Athens, April 1969. Vienne: AIEA, 1969, 325-336.

C23. CONARD R.A. et al. Medical survey of the people of Rongelap and Utirik islands thirteen, fourteen, and fifteen years after exposure to fallout radiation. BNL50220, 1970.

C24. CONARD R.A., DOBYNS B.M., SUTOW W.W. Thyroid neoplasia as a late effect of acute exposure to radioactive iodines in fallout. JAMA, 1970, 214, 316-324.

C25. CONARD R.A. et al. A twenty-year review of medical findings in a Marshallese population accidentally exposed to radioactive fallout. BNL-50424, 1975.

C26. CONARD R.A. Summary of thyroid findings in Marshallese 22 years after exposure to radioactive fallout. In: Radiation-associated thyroid carcinoma (De Groot et all., Eds.). New York: Grune and Stratton, 1977, 241-257.

C27. CONARD R.A. et al. Review of medical findings in a Marshallese population twenty-six years after accidental exposure to radioactive fallout. BNL-51261, 1980.

C28. CONARD R.A. The 1954 Bikini atoll incident: an update of the findings in the Marshallese people. In: The medical basis for radiation accident preparedness. (Hübner K.F. and Fry S.A., Eds.). New York : Elsevier, 1980, 55-58.

C29. CONARD R.A. Late radiation effects in Marshall islanders exposed to fallout 28 years ago. In: Radiation carcinogenesis: epidemiology and biological significance. (Boice J.D., Jr, Fraumeni J.F., Jr, Eds). New York: Raven Press, 1984, 5771.

C30. COTTRELL W.B. The SL-1 accident. Nucl. Safety, 1962, 3, 64-74.

C31. CRONKITE E.P. et al. Twelve-month postexposure survey on Marshallese exposed to fallout radiation. BNL-384, 1955.

C32. CRONKITE E.P., BOND V.P., DUNHAM C.L., Eds. Some effects of ionizing radiation on human beings: a report on the Marshallese and Americans accidentally exposed to radiation fallout and a discussion of radiation injury in the human being. TID-5385, 1956.

C33. CROSSAN I.F. Over-exposure from working with an X-ray crystallography set. Radiol. Prot. Bull., 1975, 13, 19-20.

D1. DANIEL J. Depilatory action of the X-rays. Med. Record, 896, 49, 595.

D2. DANIEL J. The X-rays. New Sciences, 1896, 3, 562.

D3. DAVIS J.S. Clinical illustrations of deep roentgen-ray and radium burns. Am. J. Roentgenol. Rad. Therapy, 1933, 29, 43-78.

D4. DEGOS M.M., GAULTIER F., FOURNIER F., DANIEL F. et al. Radionécrose par l'iridium 192. Société française de dermatologie et de syphiligraphie, 1969, 76, 19-20.

D5. DIXON D.W. Over-exposure of a radiographer on a construction site. Radiol. Prot. Bull. 1977, 19, 22-23. 
D6. DOLOY M.T., LE GÔ R., DUCATEZ G. et al. Utilisation des analyses chromosomiques pour l'estimation d'une irradiation accidentelle chez l'homme. In: 4. International congress of IRPA, Paris, 1977, 4, 1199-1202.

D7. DOLPHIN G.W., BOLTON D., HUMPHREY D.L.O. et al. Biological and physical dosimetry after a radiation accident. Nature, 1970, 227, 165.

D8. DONEV I., ZHIVKOV S., KIROV K., VASCOV L., BOULANOV I. Clinico-laboratory and cytogenetic observations of persons subjected to professional irradiation with gamma-neutron sources. Strahlentherapie, 1969, 138, 197-204.

D9. DOUSSET M., JAMMET $H$. Les accidents humains d'irradiation d'origine nucléaire. In: Irradiations accidentelles et therapeutiques, Créteil, Juin 1984 (Galle P., Masse R., Nenot J.C., Eds). Paris: Masson, 1984, 27-61.

D10. DZIUKA E., MERTA A., BOCIAN E. Accidental irradiation of skin on hands with a proton beam of $4 \mathrm{MeV}$ energy. Strahlentherapie, 1973, 146 (6) 685-692.

E1. ELLIOT G.A. Accidental acute irradiation from cobalt-60. South African Med. J., 1960, 34, 524-529.

E2. EURATOM. Accidental irradiation at place of work. Les irradiations accidentelles en milieu de travail, Nice, 25-29 avril 1966. EUR-3666, 1967.

E3. EVANS J.C., ORR R.G. Report on over-irradiation of a research worker's hand: physical and clinical dosimetry. In: Handling of radiation accidents, Vienna, 1923 May 1969. Vienne: AIEA, 1969, 431-435.

F1. FANGER H., LUSHBAUGH C.C. Radiation death from cardiovascular shock following a criticality accident. Arch. Pathol. 1967, 83, 446-460.

F2. FLATBY J., HENRIKSEN T., HOST H. The radiation accident at the Institute for energy technology, Kjeller, Norway, September 2, 1982: dosimetric evaluations. SIS report 1983/4, 1983.

F3. FLIEDNER T.M., CRONKITE E.P., BOND U.P., RUBINI J.R., ANDREWS G. The mitotic index of human bone marrow in healthy individuals and irradiated human beings. Acta Haematol., 1959, 22 (2) 65-79.

F4. FOREMAN H. Medical management of radioactively contaminated wounds. In: Diagnosis and treatment of radioactive poisoning, Vienna, 15-18 October 1962. Vienne: AIEA, 1963, 387-417.

F5. FROMAN D. Preliminary report on the accident in Parajito laboratory, Los Alamos on May 21, 1946. Memorandum report, Los Alamos Scientific Laboratory, Los Alamos, NM.

F6. FRY S.A. Communication personnelle.

F7. FUQUA P.A., NORWOOD W.D., MARKS S. Biological effects of human radiation exposure. Report of a criticality accident. J. Occupat. Med., 1965, 7 (3) 85-93.

G1. GELLER L.I. A case of radiation sickness due to radiocesium (en russe). Medits Radiol., 1963, 9 (2) 23-25.

G2. GEMBITSKY E.U., KOLESNIK F.A., VENTSENOSTSEV B.B. A case of acute radiation sickness in man (en russe). Medits Radiol., 1970, 15 (8) 48-54.

G3. GERBER G., KUROHARA S., ALTMAN K.I., HEMPELMANN L.H. Urinary excretion of several metabolites in persons accidentally exposed to ionizing radiation. Radiat. Res., 1961, 15, 314-318.

G4. GILBERTI M.V. The 1967 radiation accident near Pittsburgh, Pennsylvania and a follow-up report. In: The medical basis for radiation accident preparedness (Hübner K.F., Fry S.A., Eds.). New York: Elsevier, 1980, 131-140. 
G5. GILLIES H.D., McINDOE A.H. The role of plastic surgery in burns due to roentgen rays and radium. Ann. Surg., 1935, 101, 979-996.

G6. GIMENEZ J.C. communication personnelle.

G7. GOH K. Total body irradiation and human chromosomes: cytogenetic studies of the peripheral blood and bone marrow leukocytes seven years after total body irradiation. Radiat. Res., 1968, 35, 155-170.

G8. GONGORA R. Accidental radiation injuries: radiation burns. In: Emergency and disaster medicine, 3. world congress, Rome, May 24-27, 1984, 347-354.

G9. GONGORA R. Irradiation globale aiguë: Symptomatologie clinique et principes thérapeutiques (communication personnelle).

G10. GONGORA R. Inventaire et bilan des accidents radiologiques. Paris: Institut Curie et Centre international de radiopathologie, 1984.

G11. GONGORA R., JAMMET H. (communication personnelle).

G12. GONZALEZ R., BERUMEN L. Etude de cinq sujets soumis à une irradiation totale subaiguë accidentelle. Rev. Franç. Et. Clin. Biol., 1963, 8, 1009-1011.

G13. GRABIGER R., NEHRKORN O. Strahlenschädigung der rechten Hand als Folge eines Betriebsunfalles. Strahlentherapie, 1964, 123 (1) 132-138.

G14. GREEN N. Accidental exposure of a maintenance engineer. Radiol. Prot. Bull., $1976,14,14-15$.

G15. GUSKOVA A.K., BAISOGOLOV G.D. Two cases of acute radiation disease in man. In: international conference on the peaceful uses of atomic energy, Geneva, 1955. New York: United Nations, 1956, 11, 35-44.

G16. GUSKOVA A.K., ABDULAEVA V.M., NOVIKOVA L.V., SOKOLINA L.L. Local radiation affection of the head (en russe). Medits Radiol., 1969, 14 (5) 26-32.

G17. GUSKOVA A.K., SADCHIKOVA E.N., ORLYANSKAYA R.L. The importance of biochemical investigations in radiation lesions in man (en russe). Medits. Radiol., 1971, 16 (4) 52-59.

G18. GUSKOVA A.K. Clinical aspects of radiation injury simulation and recuperation (en russe) Medits. Radiol., 1972, 17 (8) 7-15.

G19. GUSKOVA A.K., RYADOV V.G., DIBOBES I.K. Specific features of acute radiation sickness under different conditions of irradiation (en russe). Medits. Radiol., 1973, 18 (4) 70-78.

G20. GUSKOVA A.K. et al. Results of clinico-physiological observations over persons exposed to occupational irradiation (en russe). Medits. Radiol., 1975, 20 (9) 3646.

H1. HANKINS D.E., HANSEN G.E. Revised dose estimates for the criticality excursion at Los Alamos Scientific Laboratory May, 21, 1946. LA-3861, 1968.

H2. HARRIS P.S. Radiation dose estimation in the 1958 Los Alamos criticality accident. Health Phys., 1961, 5, 37-44.

H3. HARRIS P.S. Acute radiation death resulting from accidental nuclear critical excursion. 6. Dosimetric calculations. J. Occup. Med., 1961, special suppl. 3 (2), 178-183.

H4. HARRISON N.T., ESCOTT P.C., DOLPHIN G.W. et al. The investigation and reconstruction of a severe radiation injury to an industrial radiographer in Scotland. In: 3. International congress of the IRPA, Washington, 1973. CONF-730907, $1974,760-768$. 
H5. HASHIZUME T., KATO Y., NAKAJIMA T., YAMAGUCHI H., FUJIMOTO K. Emergent dose estimation of non-occupational persons accidentally exposed to ${ }^{192} \mathrm{lr}$ gamma-rays. Health Phys., 1972, 23, 855-857.

H6. HASHIZUME T., KATO Y., NAKAJIMA T., YAMAGUCHI H., FUJIMOTO K. Dose estimation of non-occupational persons accidentally exposed to ${ }^{192} \mathrm{Ir}$ gamma rays. J. Radiat. Res., 1973, 14, 320-327.

H7. HASTERLIK R.J., MARINELLI L.D. Physical dosimetry and clinical observations on four human beings involved in an accidental critical assembly excursion. International conference on the peaceful uses of atomic energy, Geneva, 8-20 August, 1955, 11, 25-34.

H8. HEID K.R., BREITENSTEIN B.D., PALMER H.E. et al. The 1976 Hanford americium accident. TID-28938, 1979.

H9. HEID K.R., BREITENSTEIN B.D., PALMER H.E., MCMURRAY B.J., WALD N. The 1976 Hanford americium accident. In : The medical basis for radiation accident preparedness (Hübner K.F., Fry S.A., Eds.). New York: Elsevier, 1980, 345-355.

H10. HEMPELMANN L.H., LISCO H., HOFFMAN J.E. The acute radiation syndrome. A study of nine cases and a review of the problem. Ann. Intern. Med., 1952, 36 (2) 279-510.

H11. HEMPELMANN L.H. The assessment of acute radiation injury. In: Diagnosis and treatment of acute radiation injury, Geneva 17-20 October 1960. Genève: OMS, 1961, 49-66.

H12. HEMPELMANN L.H., LUSHBAUGH C.C., VOELZ G.L. What happened to the survivors of the early Los Alamos nuclear accidents ? In: the medical basis for radiation accident preparedness (Hübner K.F., Fry S.A., Eds.), New York: Elsevier, $1980,18-32$

H13. HIRASHIMA K., ISHIHARA T., KUMATORI T., SUGIYAMA H., KURISU A. Hematological studies of six cases of accidental exposure to an iridium radiographic source. J. Radiat. Res., 1973, 14 (3) 287-296.

H14. HIRASHIMA K., SUGIYAMA H., ISHIHARA T., KURISU A., HASHIZUME T., KUMATORI T. The 1971 Chiba, Japan accident: exposure to iridium 192. In: The medical basis for radiation accident preparedness (Hübner K.F., Fry S.A., Eds.), New York: Elsevier, 1980, 179-203.

H15. HOFFMAN J.G. Radiation doses in the Parajito accident of May 21, 1946, Los Alamos scientific laboratory report LA-687, 1948.

H16. HOFFMAN J.G., HEMPELMANN L.H. Estimation of whole-body radiation doses in accidental fission burst. Am. J. Roentgenol., 1957, 77, 144.

H17. HORAN J.R., GAMMILL W.P. The health physics aspects of the SL-1 accident. Health Phys., 1963, 9, 177-186.

H18. Hot-cell operator received an estimated 400 rad dose. Nucl. Safety, 1976, 17 (4) 495-496.

H19. HOULIANG L., FONG L.C., PANG W.C. Four cases of chronic dermatitis owing to occupational radiation (en chinois). Chinese J. Radiol. Med. Prot., 1983, 3 (2) 4446 .

H20. HOWLAND J.W., INGRAM M., MERMAGEN H., HANSEN C.L. The Lockport incident: accidental partial body exposure of humans to large doses of $\mathrm{x}$-irradiation. In: Diagnosis and treatment of acute radiation injury, Geneva 17-20 October 1960. Genève: OMS, 1961, 11-26. 
H21. HÜBNER K.F. and FRY S.A., Eds. The medical basis for radiation accident preparedness. New York: Elsevier, 1980.

H22, HURST G.S., RITCHIE R.H., EMERSON L.C. Accidental radiation excursion at the Oak Ridge Y-12 Plant. 3. Determination of radiation doses. Health Phys., 1959, 2, 121-133.

11. Industry's first radiation accident studied by AEC firms. Nucleonics, 1964, 22 (9), 21 .

12. INGRAM M. Continuing clinical observations on dose estimates one year after a radiation accident. Health Phys., 1962, 8, 519-522.

13. INSTITUTE OF NUCLEAR SCIENCES "BORIS KIDRIC". Yugoslavia criticality accident october 15, 1958. Nucleonics 1959, 17 (4) 106, 154-156.

14. INSTITUTO DE RADIOPROTEÇÃO E DOSIMETRIA. COMISSÃO NACIONAL DE ENERGIA NUCLEAR (CNEN), Brésil, 1985.

15. INTERNATIONAL ATOMIC ENERGY AGENCY, WORLD HEALTH ORGANISATION. Risk evaluation for protection of the public in the event of radiation accidents (IAEA Safety Series $n^{\circ} 21$ ), Vienna: AIEA, 1967.

16. INTERNATIONAL ATOMIC ENERGY AGENCY, WORLD HEALTH ORGANISATION. Handling of radiation accidents, Vienna, 19-23 May 1969. Vienne: AIEA, 1969.

17. INTERNATIONAL ATOMIC ENERGY AGENCY. Diagnosis and treatment of incorporated radionuclides, Vienna, 8-12 December 1975, Vienne: AIEA, 1976.

18. INTERNATIONAL ATOMIC ENERGY AGENCY, WORLD HEALTH ORGANISATION. Handling of radiation accidents 1977, Vienna, 28 February - 4 March 1977. Vienne: AIEA, 1977.

19. INTERNATIONAL ATOMIC ENERGY AGENCY. The Vinca dosimetry experiment. (IAEA Technical report series $n^{\circ}$ 6). Vienne: AIEA, 1962.

110. ISHIHARA T., KOHNO S., HIRASHIMA K., KUMATORI T., SUGIYAMA H., KURISU A. Chromosome abnormalities in persons accidentally exposed to ${ }^{192} \mathrm{Ir}$ gamma rays. J. Radiat. Res., 1973, 14, 328-335.

J1. JACOBSON A., WILSON B.M., BANKS T.E., SCOTT R.M. ${ }^{192}$ Iridium overexposure in industrial radiography. Health Phys., 1977, 32, 291-293.

J2. JAMMET H., MATHÉ G., PÊNDIC B., DUPLAN J.F., MAUPIN B., LATARJET R., KALIC D., SCHWARZENBERG L., DJUKIC Z., VIGNE J. Etudes de six cas d'irradiation totale aiguë accidentelle. Rev. Franç. Et. Clin. Biol., 1959, 4, 210-225.

J3. JAMMET H.P. Traitement des personnes irradiées lors de l'accident survenu à Vinca avec le réacteur de puissance zéro. In: Diagnostic et traitement des radiolésions aiguës, Genève, 17-20 octobre 1960. Genève: OMS, 1961, 87-107.

J4. JAMMET H.P. Treatment of victims of the zero-energy reactor accident at Vinca. In: Diagnosis and treatment of acute radiation injury, Geneva, 17-20 October 1960. Genève: OMS, 1961, 83-103.

J5. JAMMET H.P., GONGORA R., LE GÔ R., MARBLĖ G., FAES M. Observation clinique et traitement d'un cas d'irradiation globale accidentelle. In: 1. International congress of radiation protection (IRPA), Roma, Sept. 1966. Oxford: Pergamon press, 1966, 2, 1249-1291. 
J6. JAMMET H. Communication. In: Les irradiations accidentelles en milieu de travail, Nice, 25-29 avril 1966. EUR-3666, 1967, 385-388.

J7. JAMMET H., STRAMBI E., GONGORA R., NENOT J.C. Intérêt de l'association des méthodes physiques et biologiques pour l'évaluation de la dose et de sa répartition dans les cas d'irradiation globale aiguë accidentelle. In: 4. International congress of IRPA, Paris, April 24-30, 1977, 3, 961-968.

J8. JAMMET H., GONGORA R., LE GÔ R., DOLOY M.T. Clinical and biological comparison of two acute accidental irradiations: Mol (1965) and Brescia (1975). In: The medical basis for radiation accident preparedness (Hübner K.F., Fry S.A., Eds.). New York: Elsevier, 1980, 91-104.

J9. JAMMET H., GONGORA R., POUILLARD P., LE GÔ R., PARMENTIER N. The 1978 Algerian accident: Four cases of protracted whole-body irradiation. In: The medical basis for radiation accident preparedness (Hübner K.F., Fry S.A., Eds.). New York: Elsevier, 1980, 113-129.

J10. JAMMET H. GONGORA R. JOCKEY P., ZUCKER J.M. The 1978 Algerian accident: Acute local exposure of two children. In: The medical basis for radiation accident preparedness (Hübner K.F., Fry S.A., Eds.). New York: Elsevier, 1980, 229-245.

J11. JARDINE G.C., HARRISON N.T. Accidental radiation exposure of two industrial radiographers. Radiol. Prot. Bull., 1974, 7, 20-22.

J12. JARDINE G.C. Accidental radiation exposure of two technicians. Radiol. Prot. Bull., 1979, 28, 25-26.

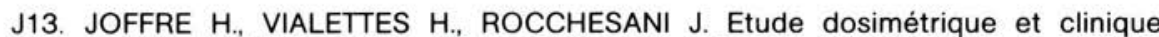
d'une exposition accidentelle subie auprès d'un accélérateur linéaire à électrons par suite d'un fonctionnement anormal. In: Personnel dosimetry for radiation accidents, Vienna, 8-12 March 1965. Vienne: AIEA, 1965, 583-595.

K1. KANN W.J., SHAFTMAN D.H., SPINRAD B.I. Postincident analyses of some aspects of the SL-1 design. Nucl. Safety, 1963, 4 (3) 39-48.

K2. KAVAS J.S., STANBURY J.B. Fatal radiation syndrome from accidental nuclear excursion. New Engl. J. Med., 1961, 262 (15) 755-761.

K3. KNOWLTON N.P., LEIFER E., HOGNESS J.R., HEMPELMAN L., BLANEY L.F., GILL D.C., OAKES W.R., SCHAFER C.L. Beta ray burns of human skin. JAMA, 1949, 141 (4) 239-246.

K4. KRETCHMAR A.L. An alteration in the excretion of free serine in urine from irradiated humans, Nature, 1959, 183, 1809-1810.

K5. KRIZEK T.J., ARIYAN S. Severe acute radiation injuries of the hands. Plast. Reconst. Surg., 1978, 51 (1) 14-22.

K6. KRUSHKOV I.K. et al. Local affection in irradiation with Iridium 192 (en russe). Medits Radiol., 1974, 19 (5) 92-94.

K7. KUMATORI T., MIYOSHI K. Clinical studies on persons injured by radioactive materials. In: Diagnosis and treatment of radioactive poisoning, Vienna, 15-18 October 1962. Vienne: AIEA, 1963, 253-284.

K8. KUMATORI T. Summary of studies on the ${ }^{192} \mathrm{Ir}$ accident. J. Radiat. Res., 1973, 14, 336-337.

K9. KUMATORI T., HIRASHIMA K., ISHIHARA T., KURISU A., SUGIYAMA H., HASHIZUME T. Radiation accident caused by an iridium-192 radiographic source. In: Handling of radiation accidents, Vienna, 28 February - 4 March, 1977. Vienne: AIEA, 1977, 35-44. 
K10. KUMATORI T. ISHIHARA T., HIRASHIMA K., SUGIYAMA H., ISHII S., MIYOSHI K. Follow-up studies over a 25-year period on the Japanese fishermen exposed to radioactive fallout in 1954. In: The medical basis for radiation accident preparedness (Hübner K.F., Fry S.A., Eds.). New York: Elsevier, 1980, 33-54.

K11. KURISU A., SUGIYAMA A., MORITA S., HIRASHIMA K., KUMATORI T. Outline of the ${ }^{192}$ Ir. accident. J. Radiat. Res., 1973, 14, 273-274.

K12. KURSHAKOV N.A., Eds. A case of acute irradiation disease in man (en russe). Moscou: Gosudartvennoe Izdatel'stov meditsinkoy literaturny, 1962 (Trad. par REACT/TS).

K13. KURSHAKOV NA., BAISOGOLOV G.D., GUSKOVA A.K., SHTUKKENBERG YU. M., DRUTMAN R.D., MALYSHEVA M.S. On the correlation of local tissue changes and general reactions at different stages of acute radiation sickness in man (en russe). Medits Radiol., 1966, 11 (4) 15-42.

L1. LANGHAM W.H. et al. Acute radiation death resulting from accidental nuclear critical excursion. 5. Special studies. J. Occup. Med., 1961, special suppl., 3 (2) 169-177.

L2. LANZL H.L., ROSENFELD M.L., TARLOV A.R. Injury due to accidental high dose exposure to $10 \mathrm{MeV}$ electrons. Health. Phys., 1967, 13, 241-251.

L3. LARSEN P.R., CONARD R.A., KNUDSEN K., ROBBINS J., WOLFF J., RALL J.E., BOBYNS B. Thyroid hypofunction appearing as delayed manifestation of accidental exposure to radioactive fallout in a Marshallese population. In: Late biological effects of ionizing radiation, Vienna, 13-17 March 1978. Vienne: AIEA $1978,1,101-115$.

L4. LARSEN P.R. et al. Thyroid hypofunction after exposure to fallout from a hydrogen bomb explosion. JAMA, 1982, 247 (11) 1571-1575.

L5. LARSON H.V., NEWTON C.E., BAUMGARTNER W.U., HEID K.R., CROOK G.H. The management of an extensive plutonium wound and the evaluation of the residual internal deposition of plutonium. Phys. Med. Biol., 1968, 13 (1) 45-53.

L6. LAWRENCE J.N.P. et al. Acute radiation death resulting from accidental nuclear critical excursion. 7. Health physics studies and area radiation levels. J. Occup. Med., 1961, special suppl., 3 (2) 184-187.

L7. LE GÔ R. Communication. In: Les irradiations accidentelles en milieu de travail, Nice, 26-29 avril 1966. EUR-3666, 1967, 373-385.

L8. LE GUEN P. A propos d'une radiodermite en milieu professionnel. Arch. Malad. Prof. 1973, 34 (4/5) 252-256.

L9. LEITH I.S. CORNELIUS W.A. Evaluation and dosimetry of accidental exposures to an X-ray analysis beam. In: 3 . International congress of the IRPA, Washington, 1973. CONF-730907, 1974, 783-790.

L10. LESSARD E.T., MILTENBERGER R., CONARD R., MUSOLINO S., NAIDU J. MOORTHY A., SCHOPFER C. Thyroid absorbed dose for people at Utirik, and Sifo on March 1, 1954. BNL-51882, 1985.

L11. LESSARD E.T., BRILL A.B., ADAMS W.H. Thyroid cancer in the Marshallese: relative risk of radioiodine and external radiation exposure. BNL-37232, 1986.

L12. LINSLEY G.S. Over-exposure during work with X-ray crystallographic equipment. Radiol. Prot. Bull., 1973, 5, 15-16.

L13. LIQUN L., WENZHENG $Z$. et al. Ten years medical follow-up of four persons accidentally exposed to ${ }^{60} \mathrm{Co} \gamma$-rays (en chinois). Chinese J. Radiol. Med. Prot. 1984,4 (2) 20-24. 
L14. LITTLEFIELD L.G., JOINER E.E. Cytogenetic follow-up studies in six radiation accident victims, 16 and 17 years post-exposure. In : Late biological effects of ionizing radiation, Vienna, 13-17 March 1978. Vienne: AIEA, 1978, 1, 297-308.

L15. LLOYD D.C., PURROTT R.J., PROSSER J.S. et al. Doses in radiation accidents investigated by chromosome aberration analysis. 8 . A review of cases investigated: 1977. NRPB-R70, 1978.

L16. LLOYD D.C., PURROTT R.J., PROSSER J.S. et al. Doses in radiation accidents investigated by chromosome aberration analysis. 9 . A review of cases investigated, 1978. NRPB-R83, 1979.

L17. LOUTIT J.F., MARLEY W.G., RUSSEL R.S. The nuclear reactor accident at Windscale, October, 1957: environmental aspects. In: Hazards to man of nuclear and allied radiations. Londres: HMSO, 1960. Appendix H., 129-139 (Cmnd. 1225).

L18. LUBENAU J.O., DAVID J.S., McDONALD D.J., GERUSKY T.M. Analytical X-ray hazards: A continuing problem. Health Phys., 1969, 16, 739-746.

L19. LUSHBAUGH C.C. et al. Acute radiation death resulting from accidental nuclear critical excursion. 2. Clinical course of case K. J. Occup. Med., special suppl., 1961, 3 (2) 150-154.

L20. LUSHBAUGH C.C. Acute radiation death resulting from accidental nuclear critical excursion. 4. Gross and microscopic pathology and neuropathology. J. Occup. Med., 1961, special suppl., 3 (2) 160-168.

L21. LUSHBAUGH C.C., FRY S.A., HÜBNER K.F., RICKS R.C. Total body irradiation : a historical review and follow-up. In: The medical basis for radiation accident preparedness. (Hübner K.F., Fry S.A., Eds.). New York: Elsevier, 1980, 3-15.

M1. MCCANDLESS J.B. Accidental acute whole-body gamma irradiation of seven clinically well persons. JAMA, 1965, 192 (3) 185-188.

M2. MCLEOD J., HOTCHKISS R.S., SITTERSON B.W. Recovery of male fertility after sterilization by nuclear radiation, JAMA, 1964, 187, 637-641.

M3. MARTINEZ R.G., CASSAB G.H., GANEM G.G. et al. Observaciones sobre la exposicion accidental de una familia a una fuente de cobalto 60. Rev. Med. Inst. Mex. Seguro Social, 1964, 3, suppl. 1, 14-68.

M4. MARSHALL E. Morocco reports lethal radiation accident. Science, 1984, 225 (4660) 395

M5. MATHÉ G., JAMMET H., PENDIC B., SCHWARZENBERG L., DUPLAN J.F., MAUPIN B., LATARJET R., LARRIEU M.J., KALIC D., DJUKIC Z. Transfusions et greffes de moëlle osseuse homologue chez des humains irradiés à haute dose accidentellement. Rev. Franç. Et. Clin. Biol., 1959, 4, 226-238.

M6. MAXFIELD W.S., PORTER G.H. Accidental radiation exposure from iridium 192 camera. In: Handling of radiation accidents, Vienna, 19-23 May 1969. Vienne: 1969, 459-467.

M7. MEDVEDEV Z. Facts behind the Soviet nuclear disaster. New Scientist, 1977, 74 (1058) 761-764.

M8. MEDVEDEV Z. Two decades of dissidence. New Scientist, 1976, 72 (1025) 264-267.

M9. MEDVEDEV Z. Nuclear Disaster in the Urals. New Scientist, 1979, 84 (1176) 115-117.

M10. MERKEL K. Un cas d'irradiation accidentelle avec un spectromètre à fluorescence. Rayonn. Ionis., 1984, N. 3, 89-98.

VOL. $22 \cdot \mathrm{N}^{\circ} 2$ 
M11. MINDER W. Interne Kontamination mit Tritium. Strahlentherapie, 1969, 137, 700704.

M12. MIYOSHI K., KUMATORI T. Characteristics of hematological findings of the Japanese fishermen exposed to radioactive ashes in the Bikini area. In: 7. International congress of hematology, Tokyo, September 4-10, 1960. Tokyo: Pan Pacific press, 1962, 29-35.

N1. NAKAMURA W. et al. Biochemical analyses of somes metabolites in urine and blood in persons exposed accidentally to ${ }^{192}$ Ir gamma rays. J. Radiat. Res., 1973, 14, 304-319.

O1. ORLOV V.M., PETUSHKOV V.N., SYCH L.I. Acute radiation affection of the hands (en russe). Medits Radiol., 1970, 15 (1) 53-56.

P1. PARKER H.M., NEWTON Jr C.E. The Hanford criticality accident: dosimetry, techniques, interpretations and problems. In: Personnel dosimetry for radiation accidents, Vienna, 8-12 March 1965. Vienne: AIEA, 1965.

P2. PARMENTIER N.C. Communication. In: Les irradiations accidentelles en milieu de travail, Nice, 26-29 avril 1966. EUR-3666, 1967, 363-371.

P3. PARMENTIER N.C., NENOT J.C., JAMMET H.J. A dosimetric study of the Belgian (1965) and Italian (1975) accidents. In: The medical basis for radiation accident preparedness (Hübner K.F., Fry S.A., Eds.). New York: Elsevier, 1980, 105-112.

P4. PARMENTIER N.C., BOULENGER R., PORTAL G. Problèmes de dosimétrie lors de l'accident de criticité survenu au réacteur Vénus à Mol, en date du 30 décembre 1965. In: 1. International congress of radiation protection (IRPA), Rome, Sept. 1966. Rome: Pergamon press, 1966, 2, 1231-1248.

P5. PAXTON H.C., BAKER R.D., MARAMAR W.J., REIDER R. Los Alamos criticality accident, December 30, 1958. Nucleonics, 1959, 17 (4) 107-108, 151.

P6. PENDIC B. The zero-energy reactor accident at Vinca. In: Diagnosis and treatment of acute radiation injury, Geneva, 17-20 October 1960. Genève: OMS, $1961,67-81$.

P7. PENELLE G. Description et analyse de l'accident de criticité survenu au réacteur Vénus à Mol en date du 30 décembre 1965. In: 1. International congress of radiation protection (IRPA), Rome, Sept. 1966. Oxford: Pergamon press, 1966, 2 1223-1230.

P8. PETERSON D.F. Acute radiation death resulting from accidental nuclear critical excursion. 3. Clinical pathology and biochemistry. J. Occup. Med., 1961, special suppl. 3 (2) 155-159.

P9. PETERSEN D.F. Neutron dose estimates in SL-1 accident. Health Phys., 1963, 9, 231-232.

P10. PETERSON D.F. Rapid estimation of fast neutron doses following radiation exposure in criticality accidents: the $S 32(n, p)$ P32 reaction in body hair. In: Personnel dosimetry for radiation accidents, Vienna, 8-12 March 1965. Vienne: AIEA, 1965, 217-233.

P11. PHILLIPS B.G. Accidental over-exposure from dental X-ray equipment. Radiol. Prot. Bull., 1976 16, 21-22.

P12. PORTER C.A. The surgical treatment of X-ray carcinoma and other severe $X$-ray lesions (based upon an analysis of 47 cases). J. Med. Res., 1909, 60, 516-524.

P13. PRETRE S., DONATH A., DUTRANNOIS J. et al. Strahlenbelastung und Dosimetrie der beruflich strahlenexponierten Personen in der Schweiz im Kalenderjahr 1978. Bern: Eidgenössisches Gesundheitsamt, 1979. 
P14. PRESTON R.J., BREWEN J.G., GENGOZIAN N. Persistence of radiation induced chromosome aberrations in marmoset and man. Radiat. Res., 1974, 60, 516-524.

P15. PURROTT R.J., DOLPHIN G.W., LLOYD D.C. et al. The study of chromosome aberration yield in human lymphocytes as an indicator of radiation dose. 2. A review of cases investigated: 1970-71. NRPB-R5, 1972.

P16. PURROTT R.J., LLOYD D.C., DOLPHIN G.W. et al. The study of chromosome aberration yield in human lymphocytes as an indicator of radiation dose. 3 . A review of cases investigated: 1971-72. NRPB-R10, 1973.

P17. PURROTT R.J., LLOYD D.C., PROSSER J.S. et al. The study of chromosome aberration yield in human lymphocytes as an indicator of radiation dose. 4. A review of cases investigated: 1973. NRPB-R23, 1974.

P18. PURROTT R.J., LLOYD D.C., PROSSER J.S. et al. The study of chromosome aberration yield in human lymphocytes as an indicator of radiation dose. 6. A review of cases investigated: 1975.

R1. RADIATION EMERGENCY ASSISTANCE CENTER, Training Site (REAC/TS). REACT/TS Newsletter, Fall 1981.

R2. RADIATION EMERGENCY ASSISTANCE CENTER, Training Site (REAC/TS). REACT/TS Newsletter, Fall 1982.

R3. RADIATION EMERGENCY ASSISTANCE CENTER, Training Site (REAC/TS). REACT/TS Newsletter, Fall 1983.

R4. RADIATION EMERGENCY ASSISTANCE CENTER, Training Site (REAC/TS). REACT/TS Newsletter, Winter/Spring 1984.

R5. RADIATION EMERGENCY ASSISTANCE CENTER, Training Site (REAC/TS). REACT/TS Newsletter, Summer/Fall 1984.

R6. RADIATION EMERGENCY ASSISTANCE CENTER, Training Site (REAC/TS). REACT/TS Newsletter, Spring 1985.

R7. RADIATION EMERGENCY ASSISTANCE CENTER, Training Site (REAC/TS), $\mathrm{REACT} / \mathrm{TS}$ radiation accident registries (communication personnelle).

R8. RADOJICIC B., HAJDUKOVIC S., ANTIC M. Follow-up studies of exposed persons in the zero energy reactor accident at Vinca. In: Diagnosis and treatment of acute radiation injury, Geneva, 17-20 October, 1960. Genève: OMS, 1961, 105-111.

R9. REVSKOY A.K., LIRMAN A.V., SHEVTSOV A.N., YAKOVLEV G.M., PERVEER V.I. Clinical picture and treatment of extensive burn caused by radiation of an electron accelerator (en russe). Medits Radiol., 1972, 17 (10) 57-63.

R10. ROBBINS L.L., AUB J.C. et al. Superficial burns of skin and eyes from scattered cathode rays. Radiology, 1946, 46, 1-23.

R11. ROSS J.P., HOLLY F.E., ZAREM H.A., ROTHMAN C.M., SHABO A.L. The 1979 Los Angeles accident. Exposure to iridium 192 industrial radiographic source. In: The medical basis for radiation accident preparedness (Hübner K.F., Fry S.A., Eds.). New York: Elsevier, 1980, 205-221.

R12. ROSSI E.C., THORNGATE A.A., LARSON F.C. Acute radiation syndrome caused by accidental exposure to cobalt-60. J. Lab. Clin. Med., 1962, 59 (4) 655-666.

R13. RUBER L.S. The Riverside radiation tragedy. Columbus Monthly, 1978 (April), $52-66$. 


\section{A. RODRIGUES DE OLIVEIRA}

S1. SAENGER L.E., KEREIAKES J.G., WALD N., THOMA G.E. Clinical course and dosimetry of acute hand injuries to industrial radiographers from multicurie sealed gamma sources. In : 3 . International congress of IRPA, Washington DC, 9-14 September 1973. CONF-73 0907, 1974, 773-782.

S2. SAFRONOV E.I. A case of radiation sickness with internal irradiation, case report. (en russe). Medits. Radiol., 1964, 10 (11) 64-71.

S3. SAGELL H. Ein Ilhrreicher Strahlenunfall. Arbeitsmed. Sozialmed. Präventivmed, $1975,24$.

S4. SAGSTUEN E., THEISEN H., HENRIKSEN T. Dosimetry by ESR spectroscopy following a radiation accident. Health Phys., 1983, 45 (5) 961-968.

S5. SCHENK R.S., GILBERTI M.V. Four extremity radiation necrosis. Arch. Surgery, $1970,100,729-734$.

S6. SCHNEIDER G.J., CHONE'S B., BLONNIGEN T. Chromosomal aberrations in a radiation accident: dosimetric and hematological aspects. Radiat. Res., 1969, 40, 613-617.

S7. SCHOFIELD G.B. Environmental health and the Windscale incident. In: The medical basis for radiation accident preparedness (Hübner K.F., Fry S.A., Eds.). New York: Elsevier, 1980, 481-489.

S8. SCOTT Jr R.L. Fuel-melting incident at the Fermi reactor on Oct. 5, 1966. Nucl. Safety, 1971, 12 (2) 123-134.

S9. SEELANTAG W. Two cases of tritium fatality. In: Tritium symposium, Las Vegas, NV, August 1971 (Moghissi A., Carter M.W., Eds). Phœnix: Messenger Graphics, 1971.

S10. SERVICE CENTRAL DE PROTECTION CONTRE LES RAYONNEMENTS IONISANTS (SCPRI). Rapports trimestriels de 1981 à 1983. Le Vésinet, France: SCPRI.

S11. SERVICE CENTRAL DE PROTECTION CONTRE LES RAYONNEMENTS IONISANTS (SCPRI). Rapports annuels 1976 à 1980. Le Vésinet, France: SCPRI.

S12. SHIPMAN T.L. A radiation fatality resulting from massive overexposure to neutrons and gamma rays. In: Diagnosis and treatment of acute radiation injury, Geneva, 17-20 October, 1960. Genève: OMS, 1961, 113-133.

S13. SHIPMAN T.L., LUSHBAUGH C.C., PETERSON D.F. et al.: Acute radiation death resulting from accidental nuclear critical excursion. J. Occup. Med., 1961, special suppl., 3 (2) 146-192.

S14. SHIPMAN T.L. Acute radiation death resulting from accidental nuclear critical excursion. 8. Report on other personnel exposed. J. Occup. Med., 1961, special suppl., 3 (2) 188-190.

S15. SISE H.S., GAUTHIER J., BECKER R., BOLGER J. Blood coagulation factors in total body irradiation. Blood, 1959, 18, 1809-1810.

S16. SL-1 explosions kills 3; cause and significance still unclear. Nucleonics, 1961, 19 (3).

S17. SORAN D.M., STILLMAN D.B. An analysis of the alleged Kyshtym disaster. LA9217-MS, 1982.

S18. STATENS INSTITUTT FOR STRALEHYGIENE. Reports of the fatal radiation accident occured at Institute for energy technology, Kjeller, Norway, 1982.

S19. STAVEM P. et al. A radiation accident with lethal outcome. J. Norwegian Med. Ass., 1983, 33 (103) 2240-2242. 
S20. STEIDLEY D.K. A ${ }^{60}$ Co hot cell accident. Health Phys., 1976, 31, 382-385.

S21. STEIDLEY D.K., ZENK G.S., OUELLETTE R. Another ${ }^{60} \mathrm{Co}$ hot cell accident. Health Phys., 1979, 36, 437-441.

S22. STEIDLEY D.K., STABILE R.J., SANFILLIPPO L.J. A case history of severe radiation burns from 50 kVc X-rays. Health Phys., 1981, 40, 399-405.

S23. STEVENS L.G. Injurious effects on the skin. Brit. Med. J., 1896, 1, 998.

S24. STIEVE F.E. Erfahrungen mit bisherigen Strahlenunfällen-Ursachen, Abläufe, Gegenmassnahmen. Strahlenschutz in Forschung und Praxis, 1980, 21, 80-108.

S25. STRATTON W.R. A review of criticality accidents. Los Alamos Scientific Laboratory report, LA-3611, 1967.

S26. SUGAHARA T., DOIDA Y., SAKURAI M., HASHIMOTO T., MINAGAWA Y. Chromosome aberrations in accidentally irradiated human subjects. Nippon Acta Radiol., 1967, 27, 129-133.

S27. SUGIYAMA H., KURISU A., HIRASHIMA K., KUMATORI T. Clinical studies on radiation injuries resulting from accidental exposure to an iridium-192 radiographic source. J. Radiat. Res., 1973, 14 (3) 275-286.

S28. SUNDARA I.S., IYER P.S., KANNAN A., ZAPARDE S.P., SUBRAHMA G. Radiation Injury from analytical $X$-ray equipment. In: 4 . International congress of IRPA. Paris, April 24-30, 1977, 3, 969-976.

S29. SWEET R.D. Acute accidental superficial X-rays burns. Brit. J. Dermatol., 1962, $74,392-402$.

S30. SWEET R.D. Treatment of acute local radiation. Clin. Radiol., 1964, 15, 55-58.

T1. THOMA G.E., WALD N. The diagnosis and management of accidental radiation injury. J. Occup. Med., 1959, 1, 421-447.

T2. THOMA G.E. Symposium on radiation accidents and emergencies in medicine, research and industry. Mid-West Chapter, Health physics society, Medical physics society of Illinois and American industrial hygiene association, Chicago, 1963, Springfield, III., 1965.

T3. TRABALKA J.R., EYMAN L.D., PARKER F.L., STRUXNESS E.G., AUERBACH S.I. Another perspective of the 1958 Soviet nuclear accident. Nucl. Safety, 1979, 20 (2) $202-210$.

T4. TRABALKA J.R., EYMAN L.D., AUERBACH S.I. Analysis of the 1957-1958 Soviet nuclear accident. Science, 1980, 209, 345-353.

T5. TRABALKA J.R., AUERBACH S.I., EYMAN L.D. Technical note: The 1957-1958 Soviet nuclear accident in the Urals. Nucl. Safety, 1980, 21 (1) 94-99.

U1. UNITED NATIONS SCIENTIFIC COMMITTEE ON THE EFFECTS OF ATOMIC RADIATION (UNSCEAR). lonizing radiation: sources and biological effects, 1982, report. New York: United Nations, 1982.

U2. UNITED NATIONS SCIENTIFIC COMMITTEE ON THE EFFECTS OF ATOMIC RADIATION (UNSCEAR). lonizing radiation: sources and biological effects, 1982, report. Annex H. New York: United Nations, 1982, 371.

U3. UNITED NATIONS SCIENTIFIC COMMITTEE ON THE EFFECTS OF ATOMIC RADIATION (UNSCEAR). lonizing radiation: sources and biological effects, 1982 , report. Annex H. (Dolphin G.W., communication personnelle, 1979), 415.

U4. UNITED NATIONS SCIENTIFIC COMMITTEE ON THE EFFECTS OF ATOMIC RADIATION (UNSCEAR). lonizing radiation: sources and biological effects, 1982 , report. Annex H. (Villforth J.C., communication personnelle 1979), 414-417. 
U5. US ATOMIC ENERGY COMMISSION (USAEC), PAN AMERICAN HEALTH ORGANIZATION. International workshop on recent advances in medical management in radiation accidents, Washington, September 16-19, 1973 (non publié).

U6. US ATOMIC ENERGY COMMISSION (USAEC). Operational accidents and radiation exposure experience. WASH-1192, 1975.

U7. US NUCLEAR REGULATORY COMMISSION (NRC). Report to congress on abnormal occurences, October-December 1976. NUREG-0090-6, 1977.

U8. US NUCLEAR REGULATORY COMMISSION (NRC). 9. annual occupational radiation exposure report, 1976. NUREG-0322, 1977.

U9. US NUCLEAR REGULATORY COMMISSION (NRC). NUREG-0090, 1981.

V1. VASSILEVA B., KRUSCHKOV I. Suizid mit Cesium 137. Psych. Neurol. Med. Psychol., 1978, 30, 116-119.

V2. VODOPICK H., ANDREWS G.A. Accidental radiation exposure. Arch. Environm. Health., 1974, 28, 53-56.

V3. VODOPICK H., ANDREWS G.A. The University of Tennessee comparative animal research laboratory accident in 1971. In: The medical basis for radiation accident preparedness (Hübner K.F., Fry S.A., Eds.). New York: Elevier, 1980, 141149.

W1. WADE L. Jr. Accidental ${ }^{60}$ Co exposure at the University of Tennessee - Atomic energy commission agricultural research laboratory. Nucl. Safety, 1972, 13 (4) 304-308.

W2. WAKABAYACHI K., ISURUGI K., TAMAOKI B., AKABOSHI S. Serum levels of luteinizing hormone ( $\mathrm{LH})$ and folliclestimulating hormone (FSH) in subjects accidentally exposed to $192 \mathrm{Ir}$ gamma rays. J. Radiat. Res., 1973, 14, 297-303.

W3. WALD N. Dosimetry and management planning. Symposium on acute radiation syndrome, Western Pennsylvania hospital, Pittsburg, 1968.

W4. WALSH D. Deep traumatism from Roentgen ray exposure. Brit. Med. J., 1897 (31 July), 272.

W5. WEIGENSBERG I.J., ASBURY C.W., FELDMAN A. Injury due to accidental exposure to X-rays fluorescence spectrometer. Health Phys., 1980, 39, 237-241.

W6. WORLD HEALTH ORGANIZATION (WHO). Diagnosis and treatment of acute radiation injury, Geneva, 17-20 October 1960. Genève: OMS, 1961.

Y1. YALCINTAS M.G., OZER H. An accident during the transfer of ${ }^{60}$ Co therapy source (abstract), 22. Annual meeting of the Health physics society. Health Phys., 1977, 33, 675-676.

Y2. YALCINTAS M.G. et al. Estimation of dose to accidental exposure to a ${ }^{60} \mathrm{Co}$ therapy source. Health Phys., 1980, 38 (2) 187-191.

Y3. YANG P., WANG Z., GUO Z. et al. Follow-up studies on three accidentally irradiated cases (en chinois) Chinese. J. Radiol. Med. Prot., 1985, 5 (3) 169-172.

Y4. YE G.Y., LIU Y., TIEN N. et al. The People's republic of China accident in 1963. In: The medical basis for radiation accident preparedness (Hübner K.F., Fry S.A., Eds.). New York: Elsevier, 1980, 81-89.

Y5. YEH K.Y., TIEN N., CHIANG B.Y. et al. 14 years follow-up of 4 cases of acute radiation sickness (abstract). 6. International congress of radiation research, Tokyo, May 1979 (non publié).

Z1. ZENGLU L., ZHIGEN W., HANGSHAN Z. Analysis of skin radiation injury in 105 cases (en chinois). Chinese J. Radiol. Med. Prot., 1985, 5 (3) 173-175. 
UN REPERTOIRE DES ACCIDENTS RADIOLOGIQUES, 1945-1985

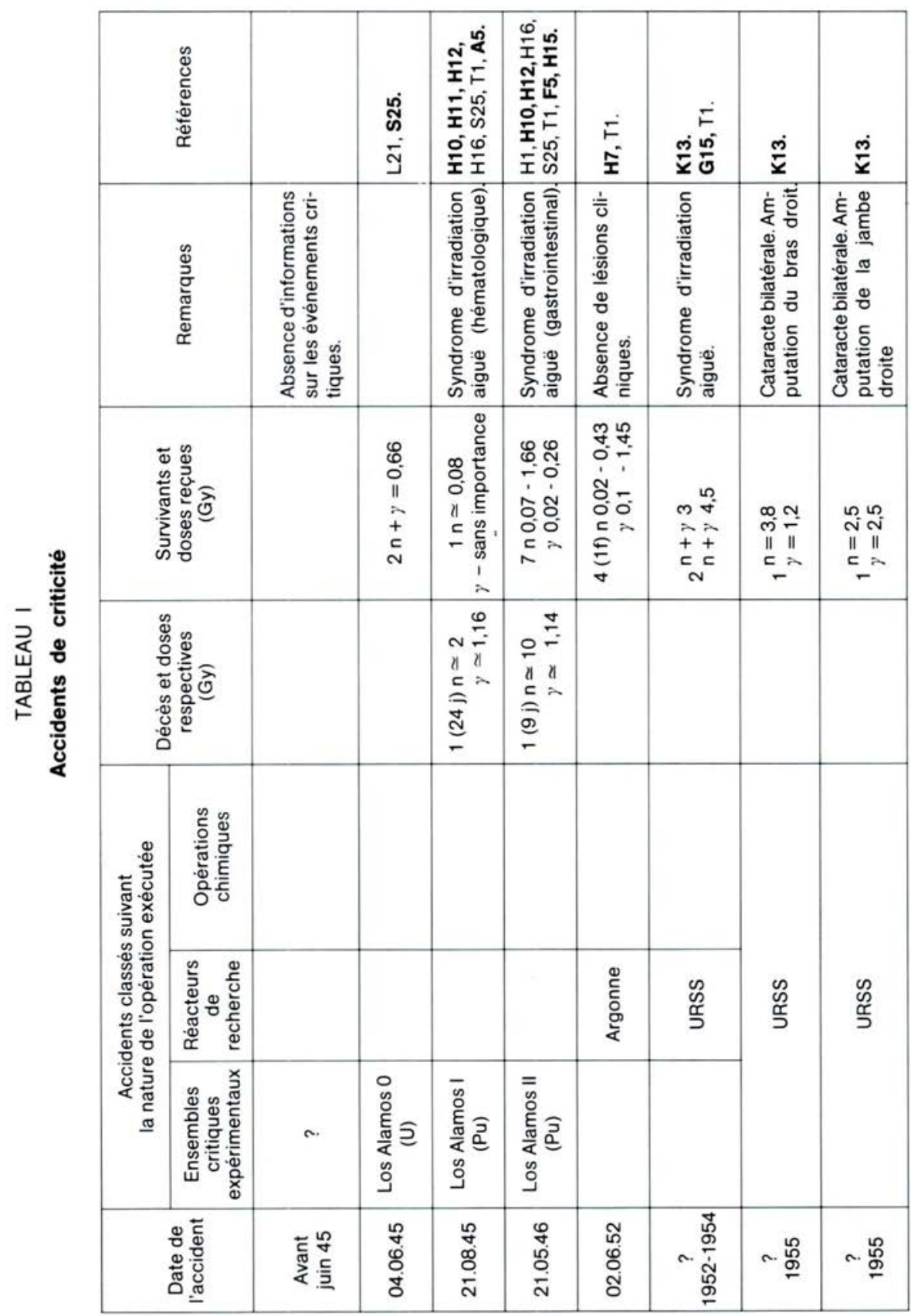

VOL. $22-\mathrm{N}^{\circ} 2$ 
A. RODRIGUES DE OLIVEIRA

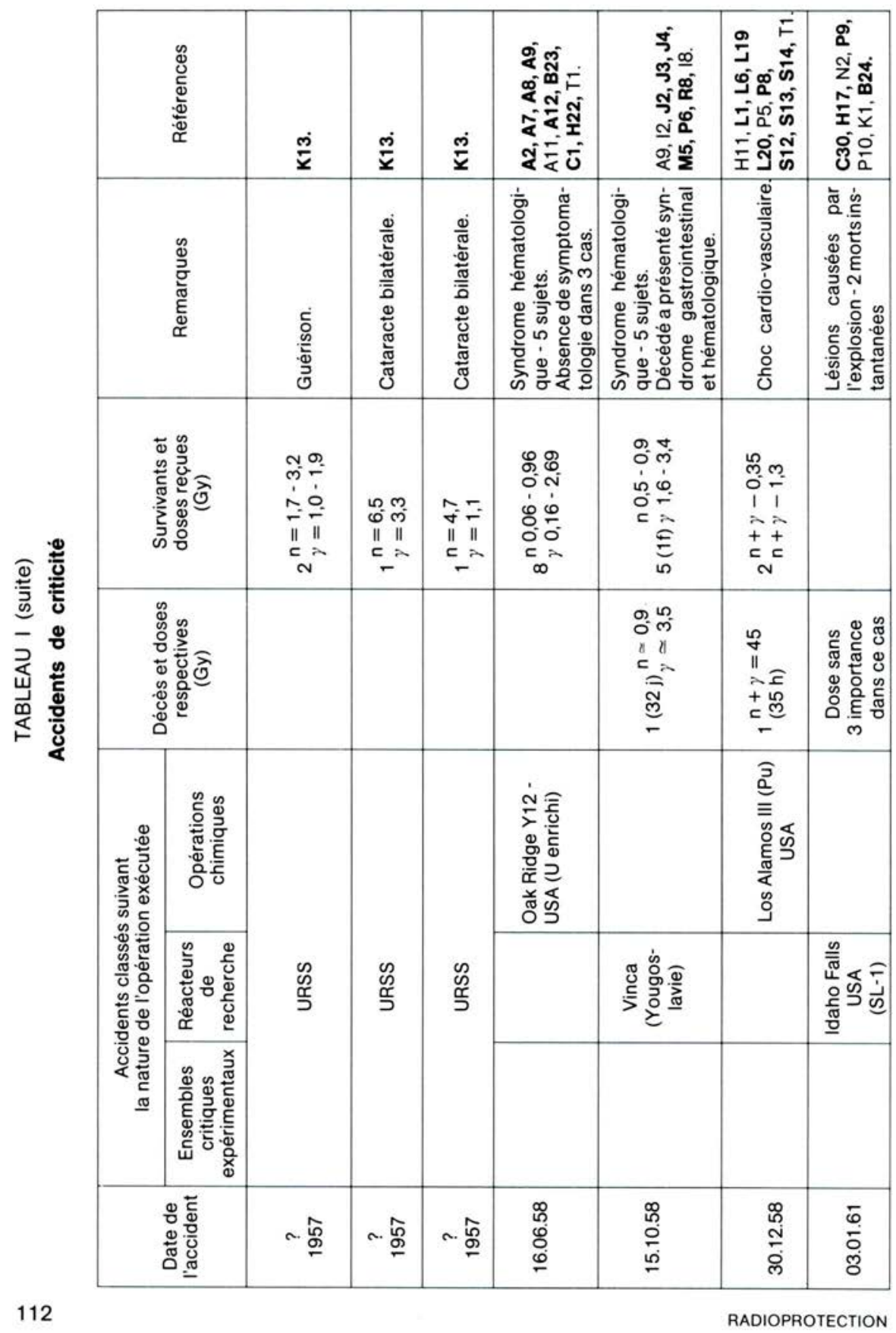


UN RÉPERTOIRE DES ACCIDENTS RADIOLOGIQUES, 1945-1985

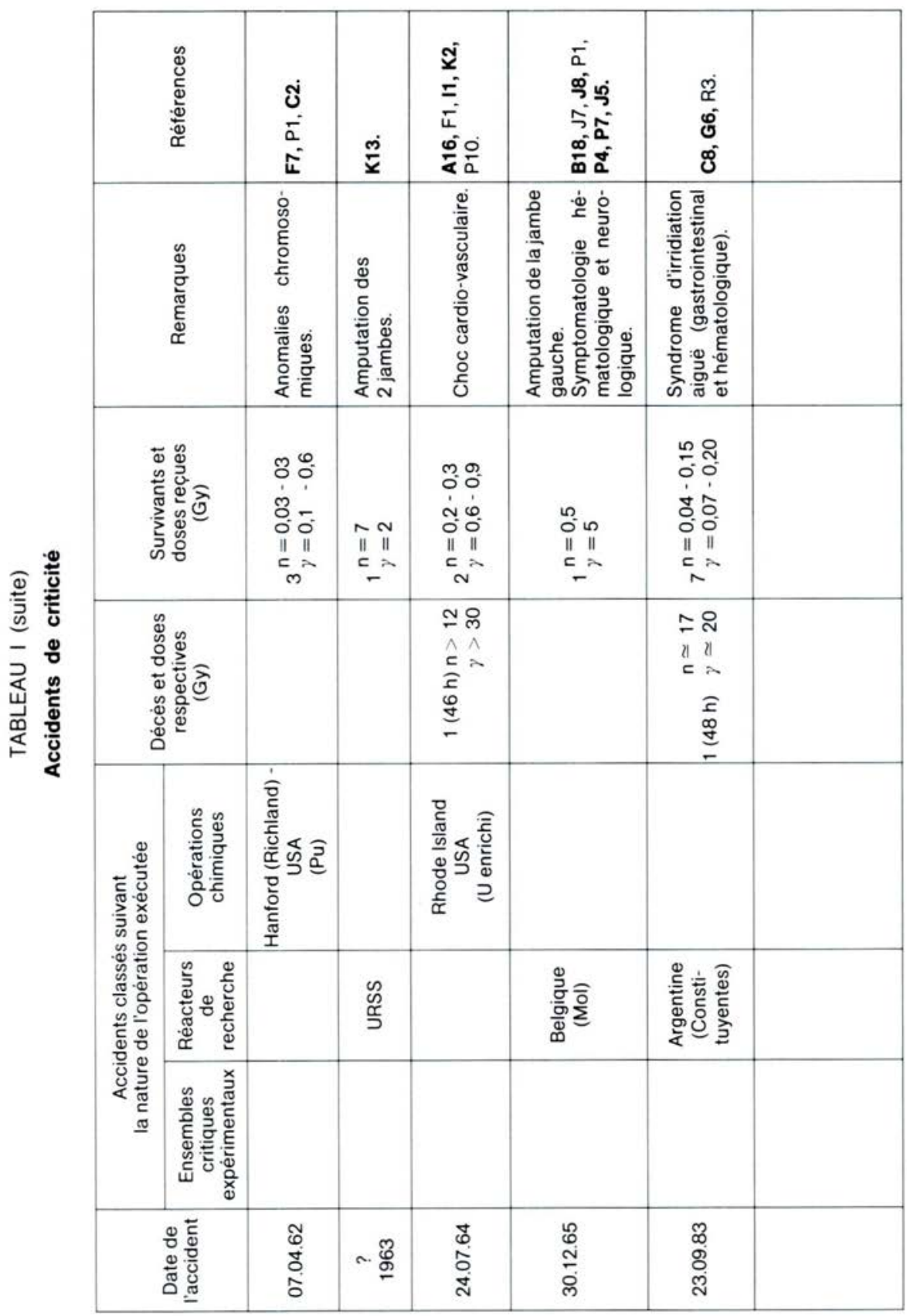


A. RODRIGUES DE OLIVEIRA

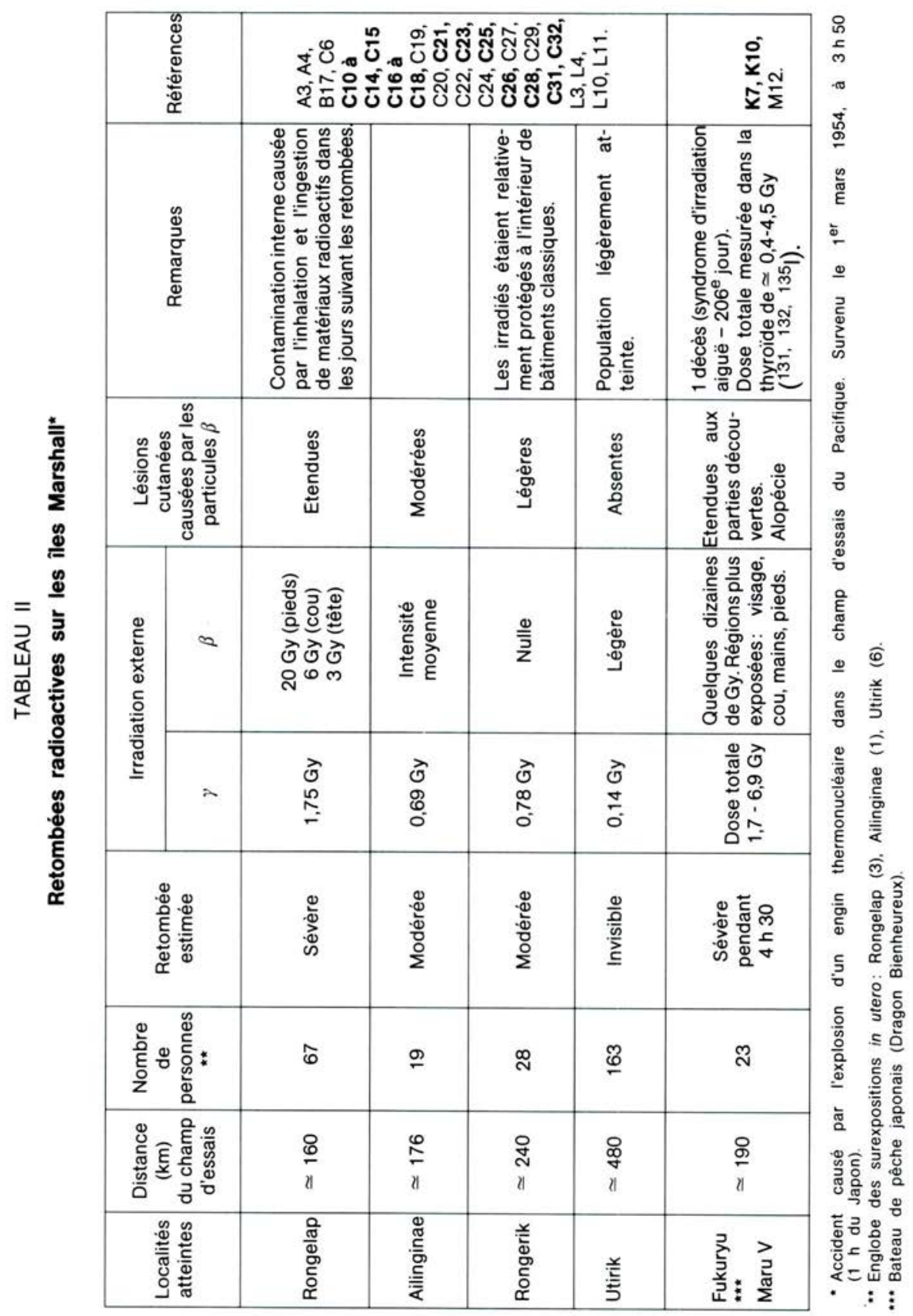


UN REPERTOIRE DES ACCIDENTS RADIOLOGIQUES, 1945-1985

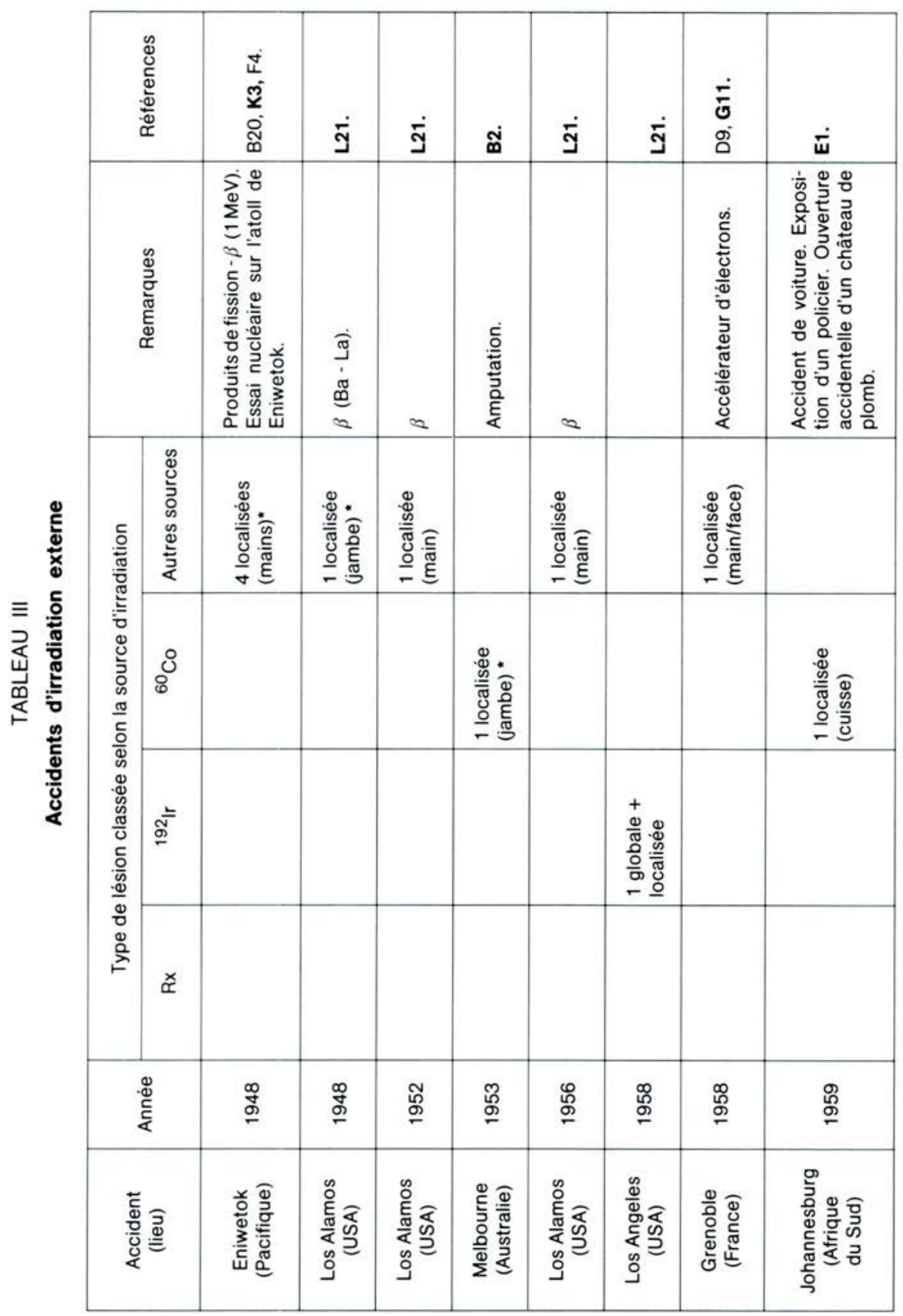

VOL. $22-\mathrm{N}^{\circ} 2$ 
A. RODRIGUES DE OLIVEIRA

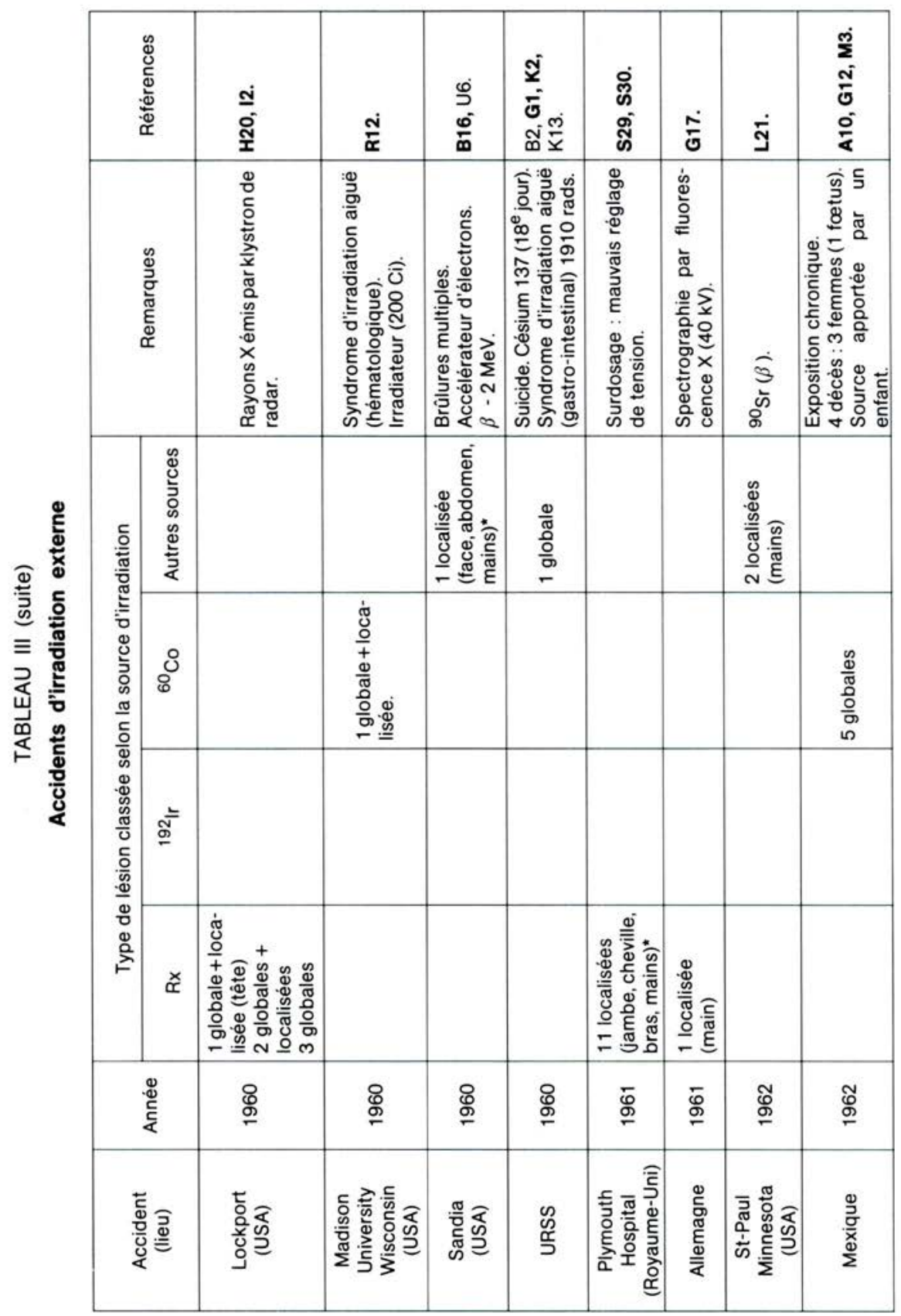


UN RÉPERTOIRE DES ACCIDENTS RADIOLOGIQUES, 1945-1985

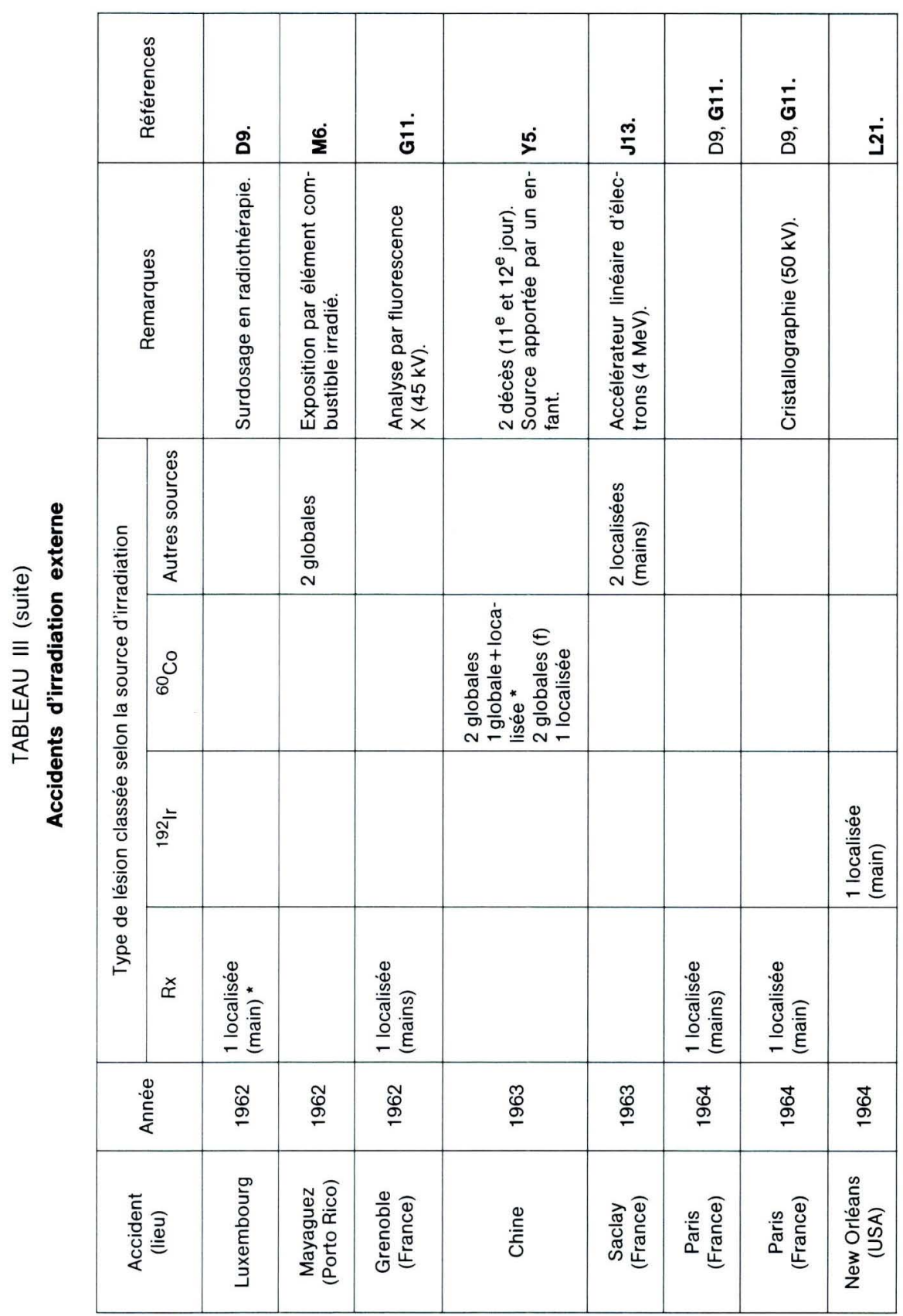

VOL. $22-\mathrm{N}^{\circ} 2$ 
A. RODRIGUES DE OLIVEIRA

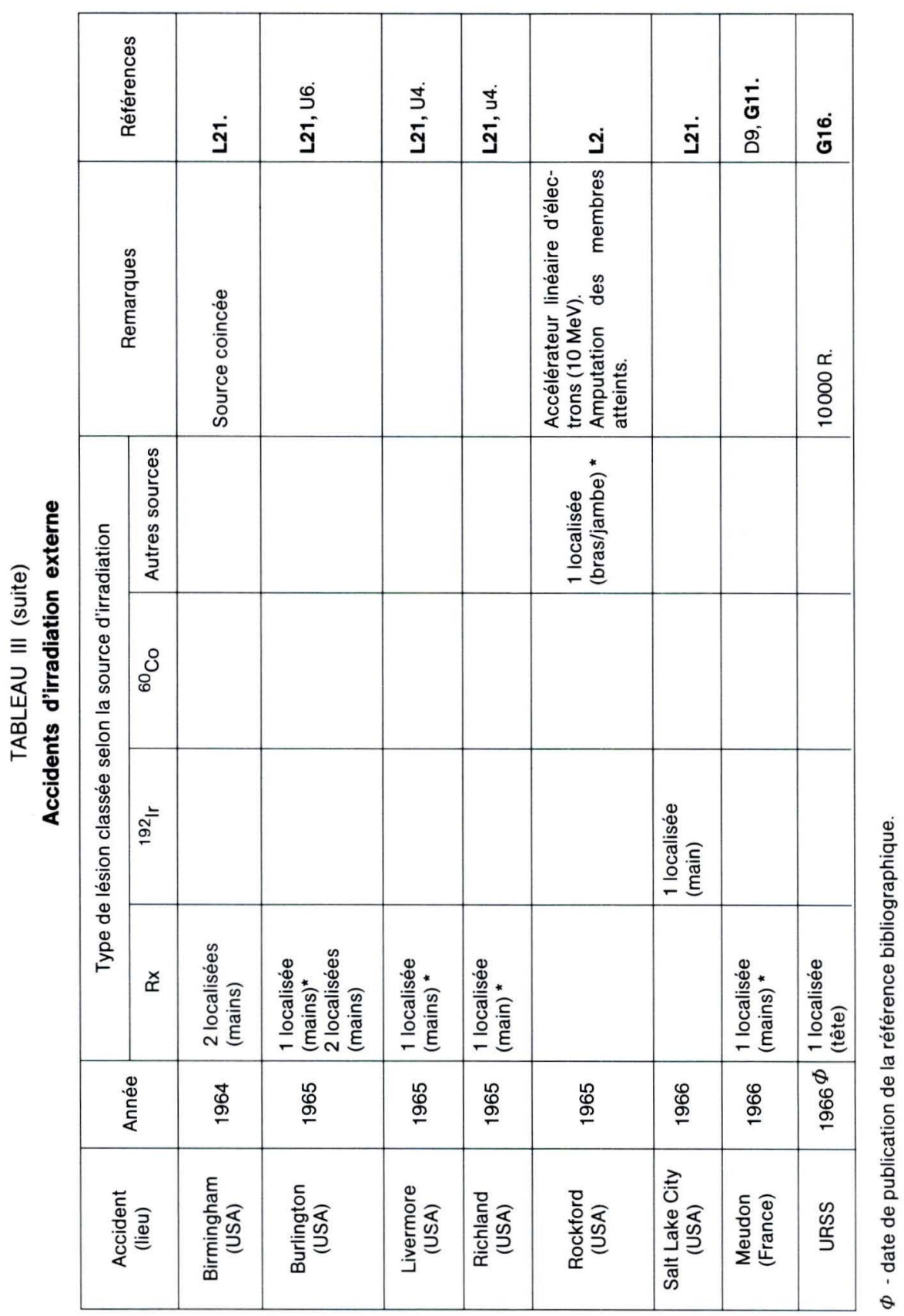


UN RÉPERTOIRE DES ACCIDENTS RADIOLOGIQUES, 1945-1985

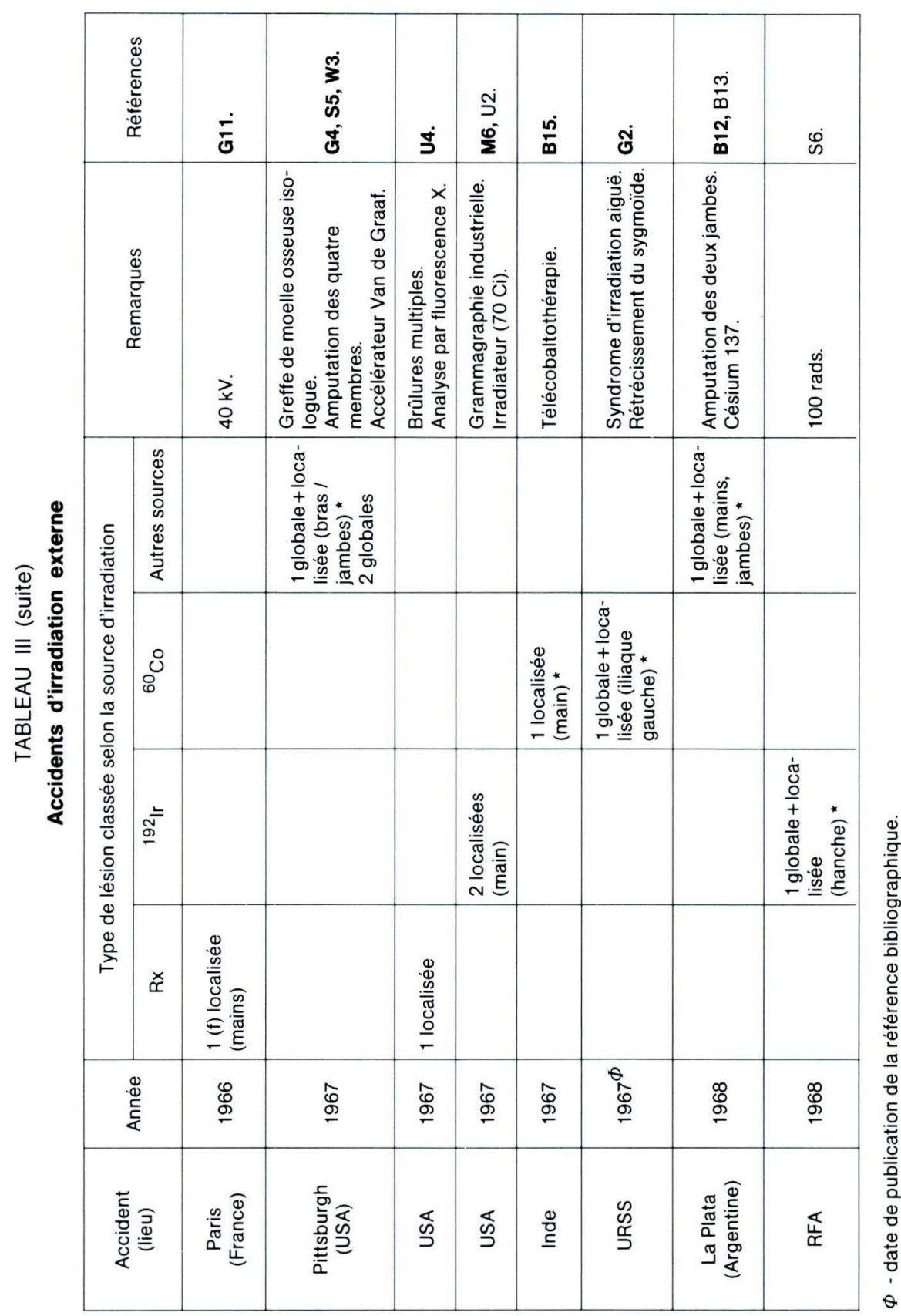

VOL. $22-\mathrm{N}^{\circ} 2$ 
A. RODRIGUES DE OLIVEIRA

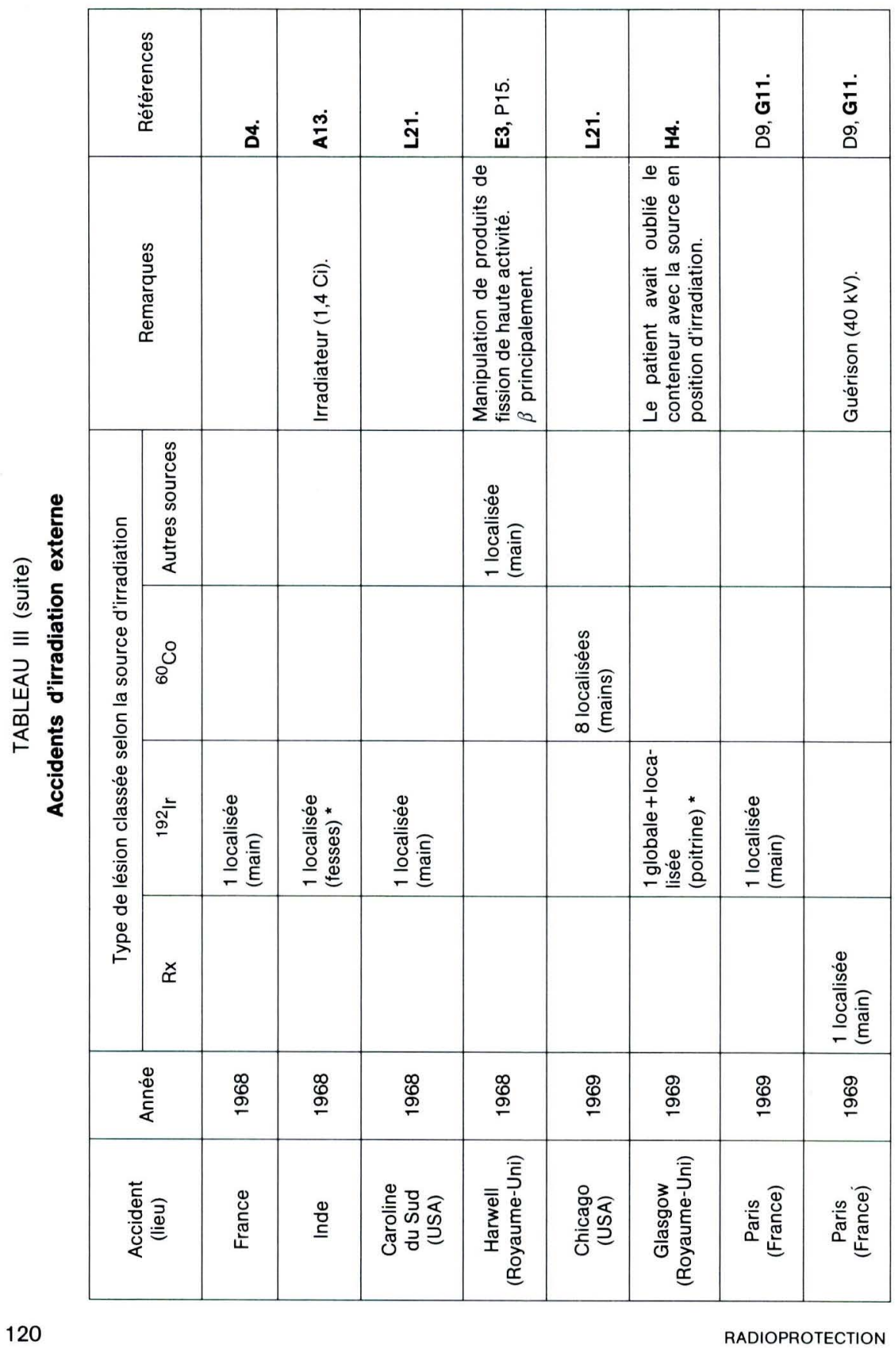


UN REPERTOIRE DES ACCIDENTS RADIOLOGIQUES, 1945-1985

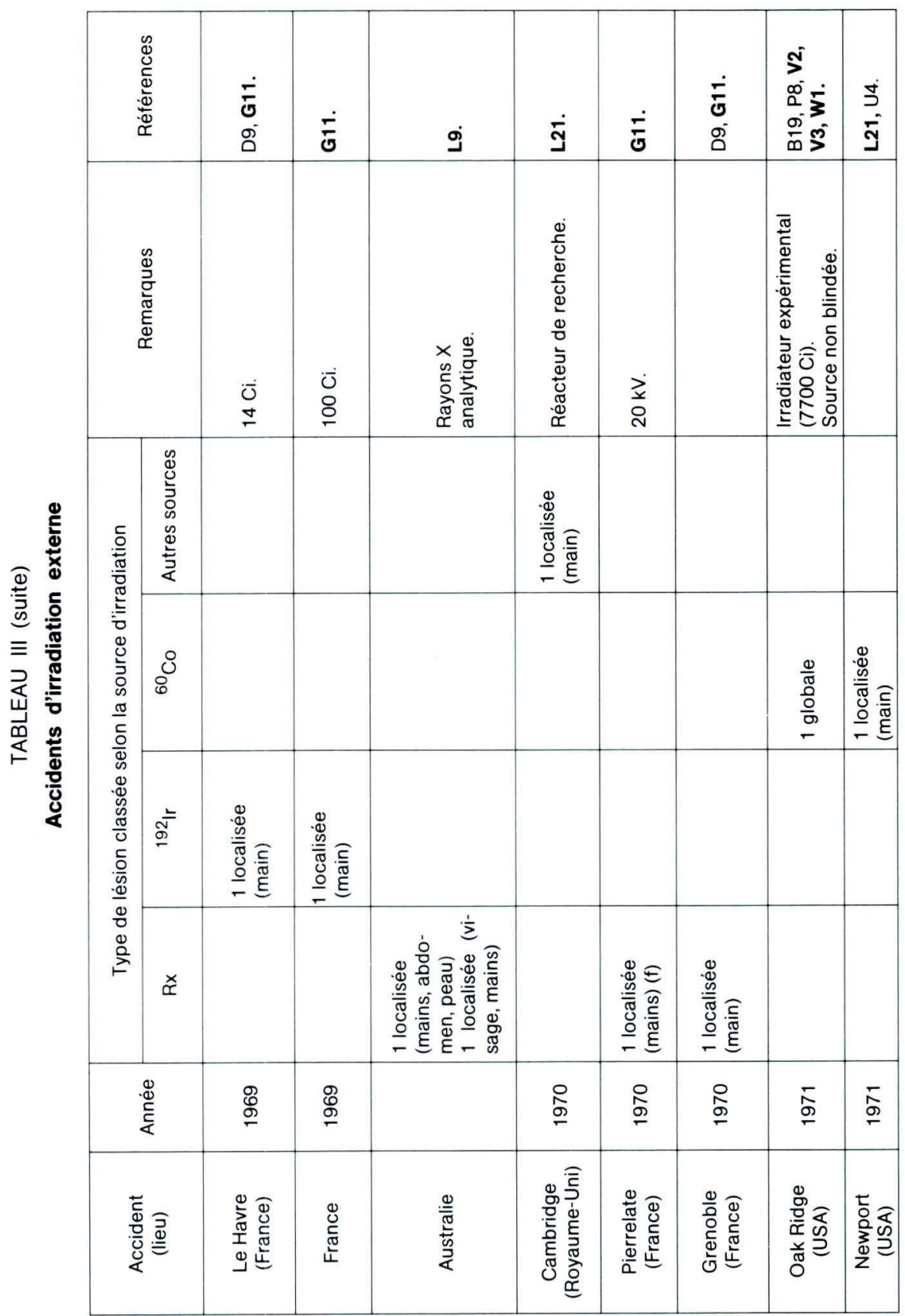


A. RODRIGUES DE OLIVEIRA

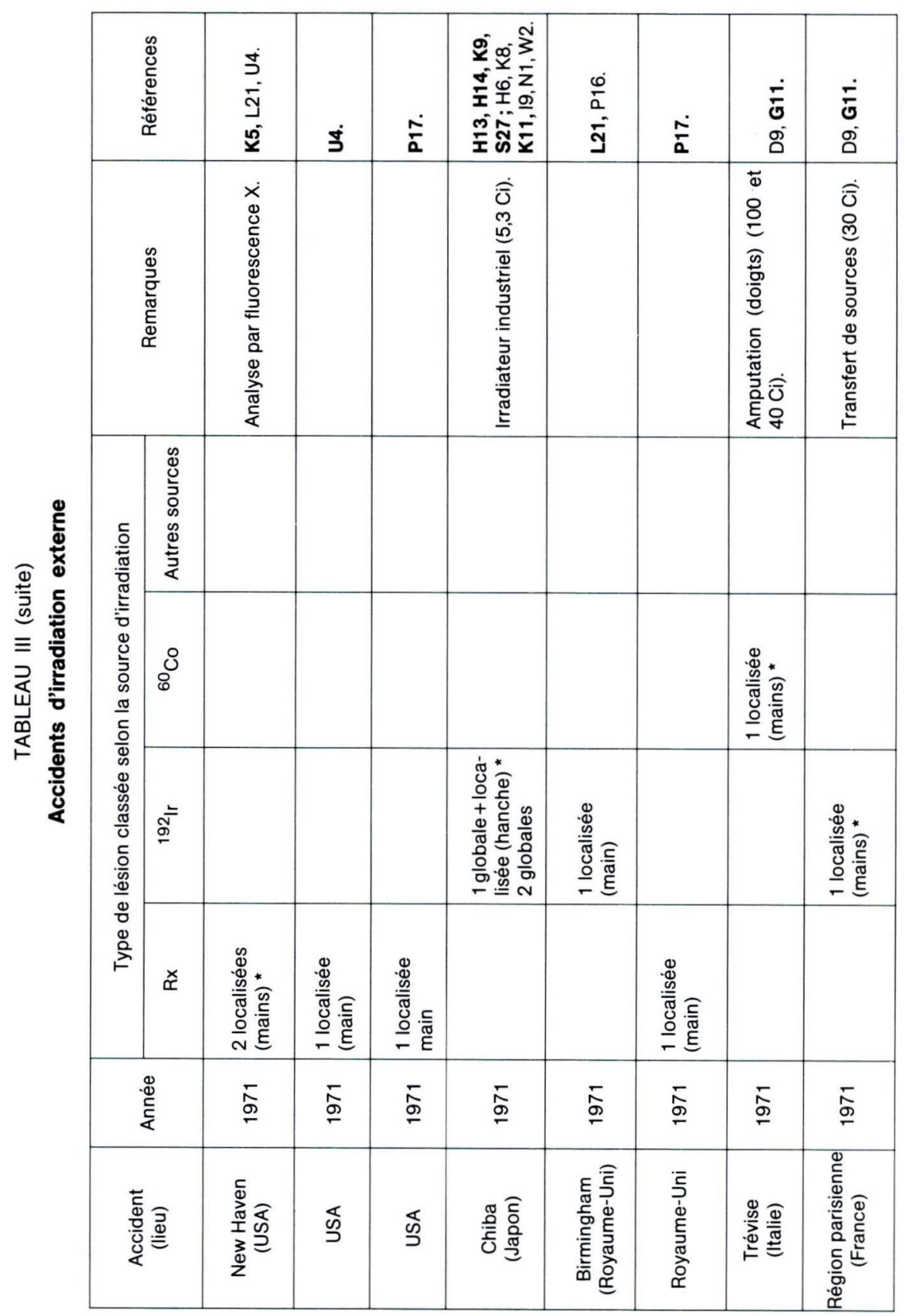


UN RÉPERTOIRE DES ACCIDENTS RADIOLOGIQUES, 1945-1985

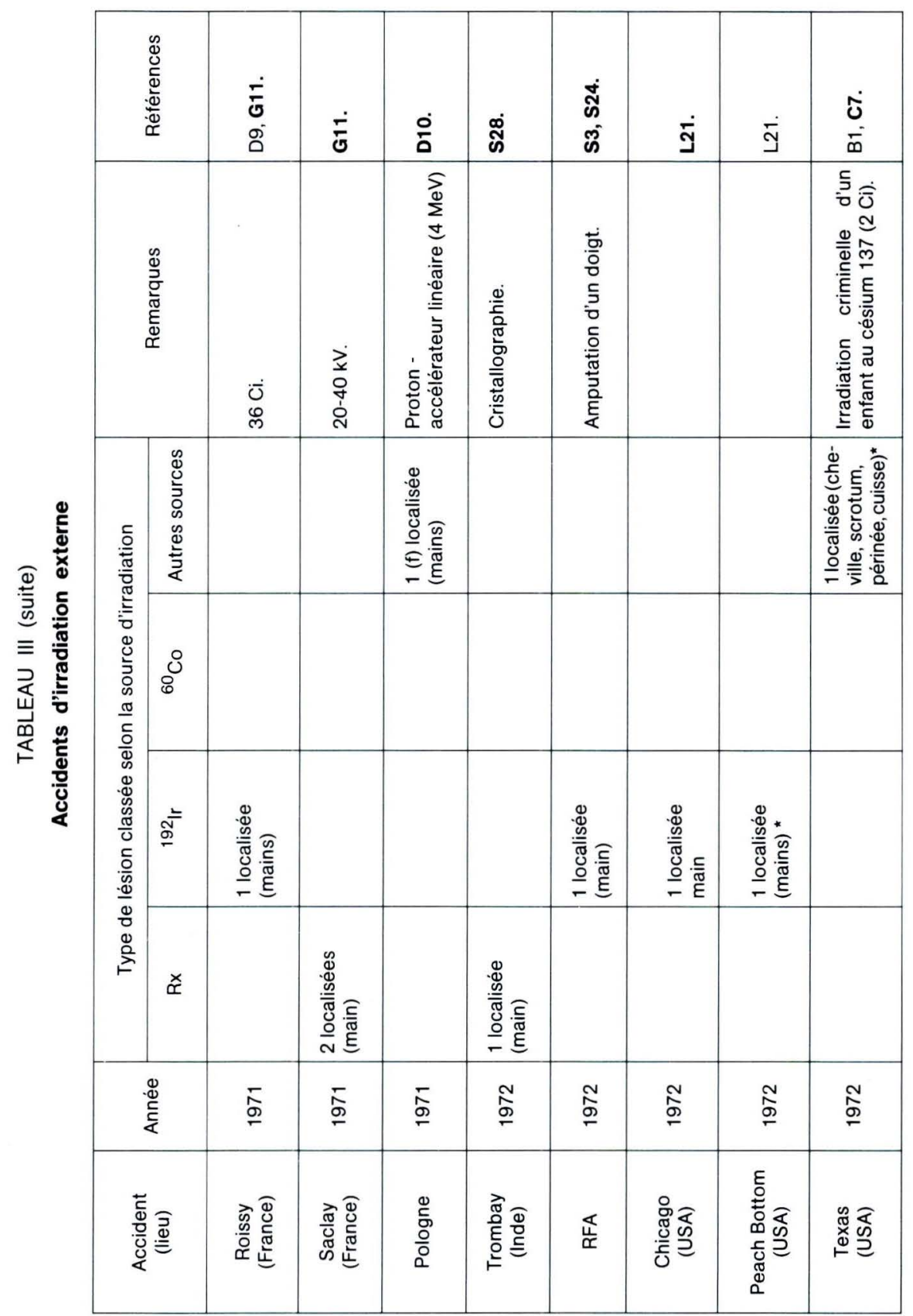

VOL. $22-\mathrm{N}^{\circ} 2$ 
A. RODRIGUES DE OLIVEIRA

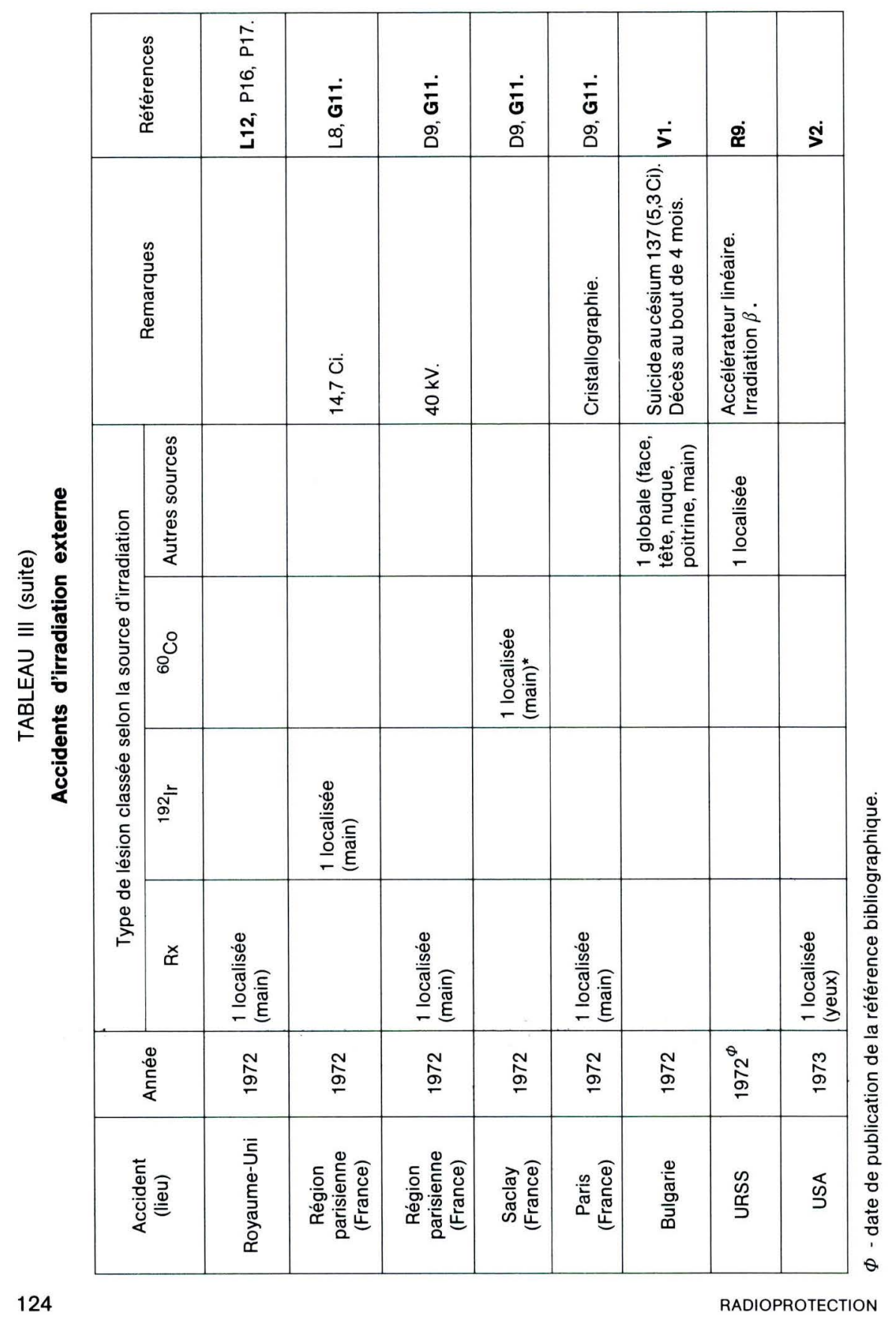


UN REPERTOIRE DES ACCIDENTS RADIOLOGIQUES, 1945-1985

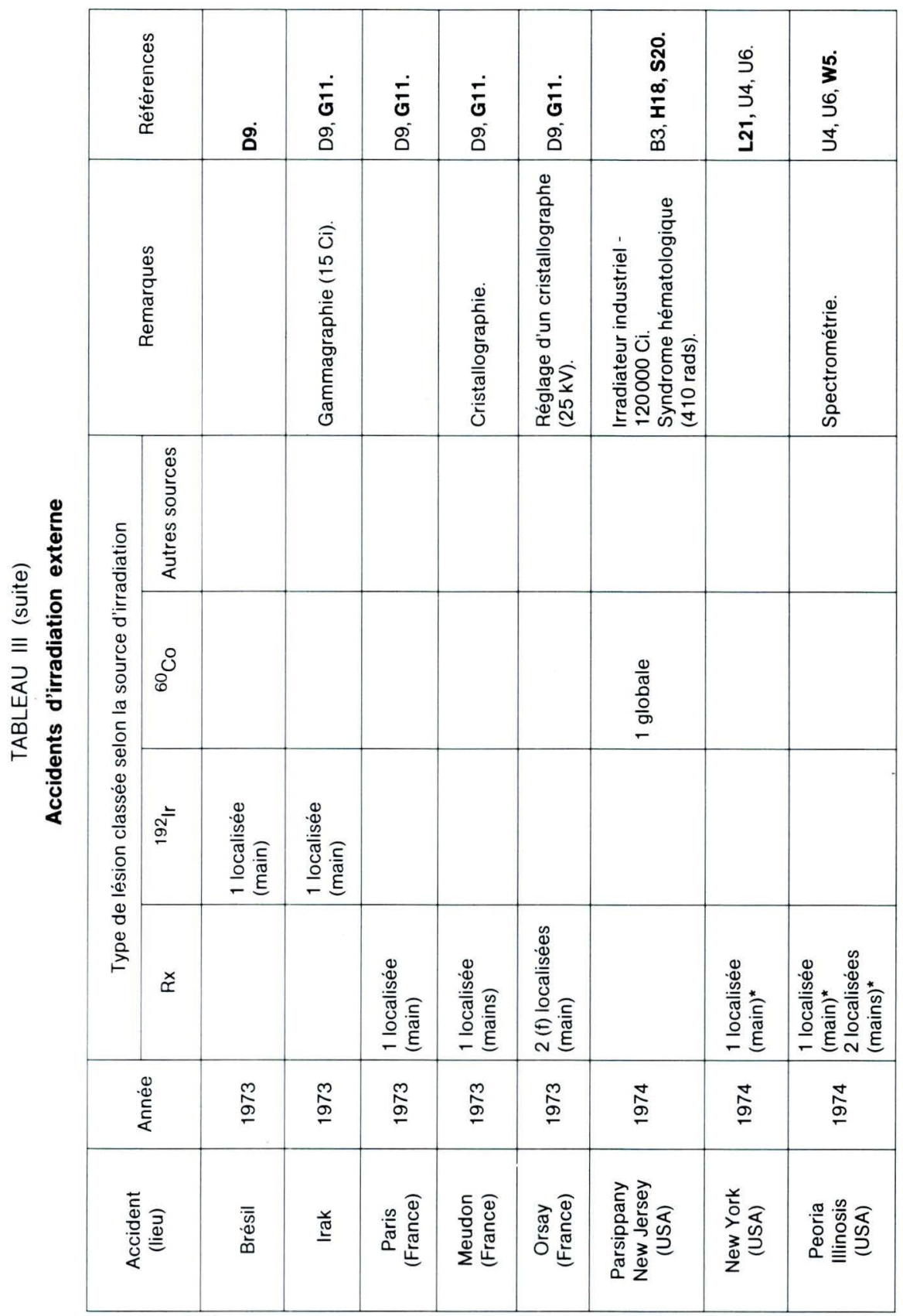


A. RODRIGUES DE OLIVEIRA

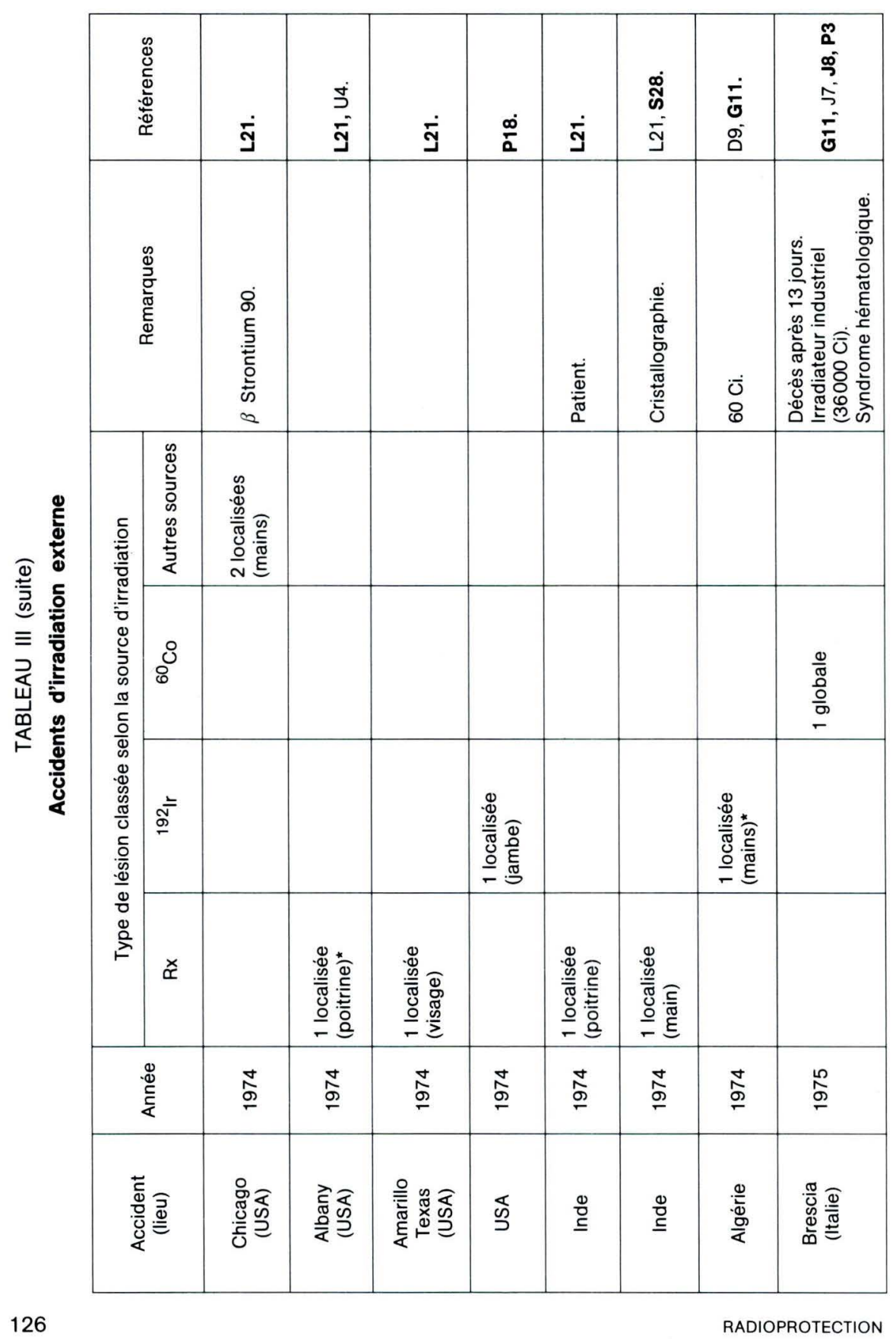


UN RÉPERTOIRE DES ACCIDENTS RADIOLOGIQUES, 1945-1985

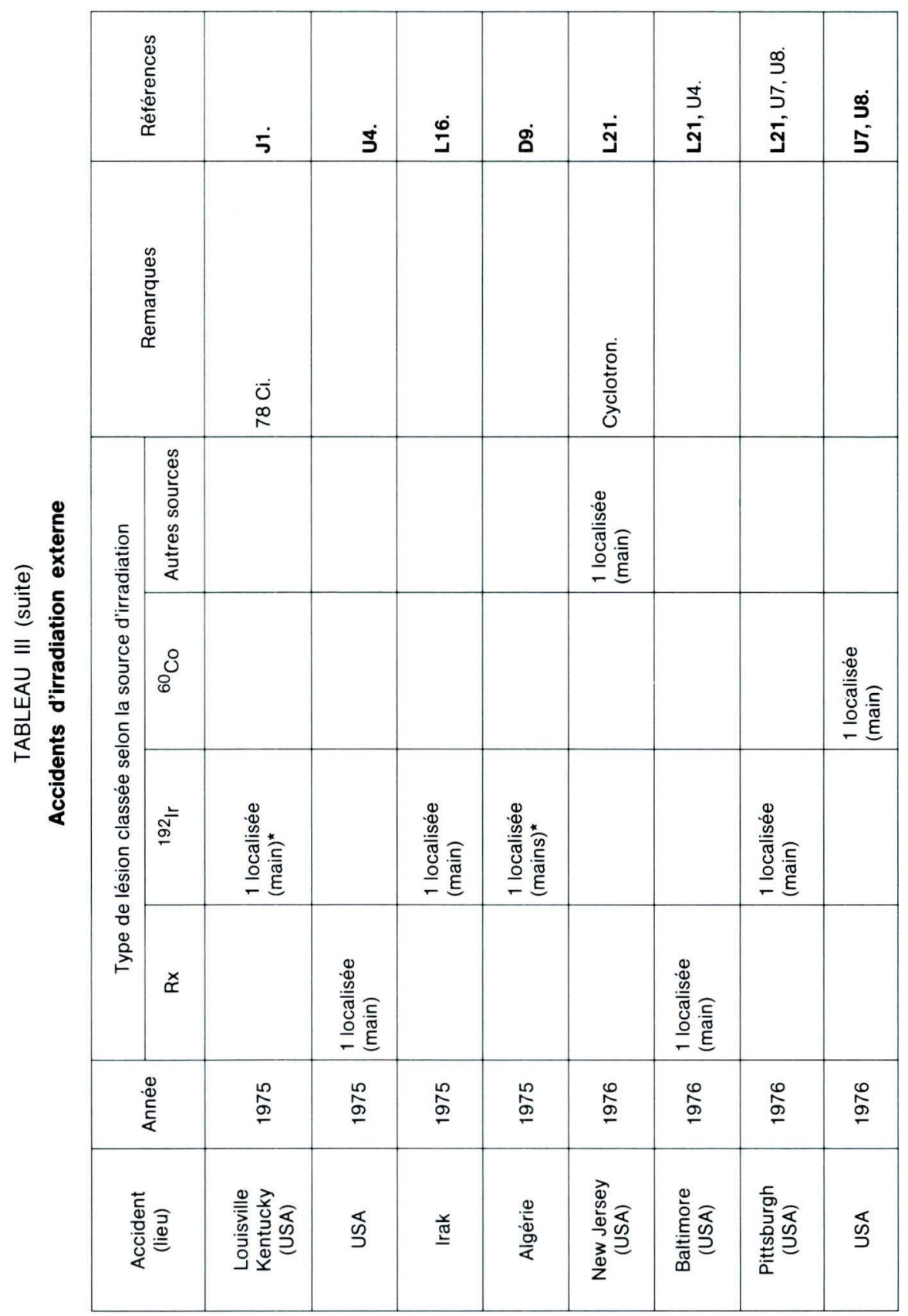

VOL. $22-\mathrm{N}^{\circ} 2$ 
A. RODRIGUES DE OLIVEIRA

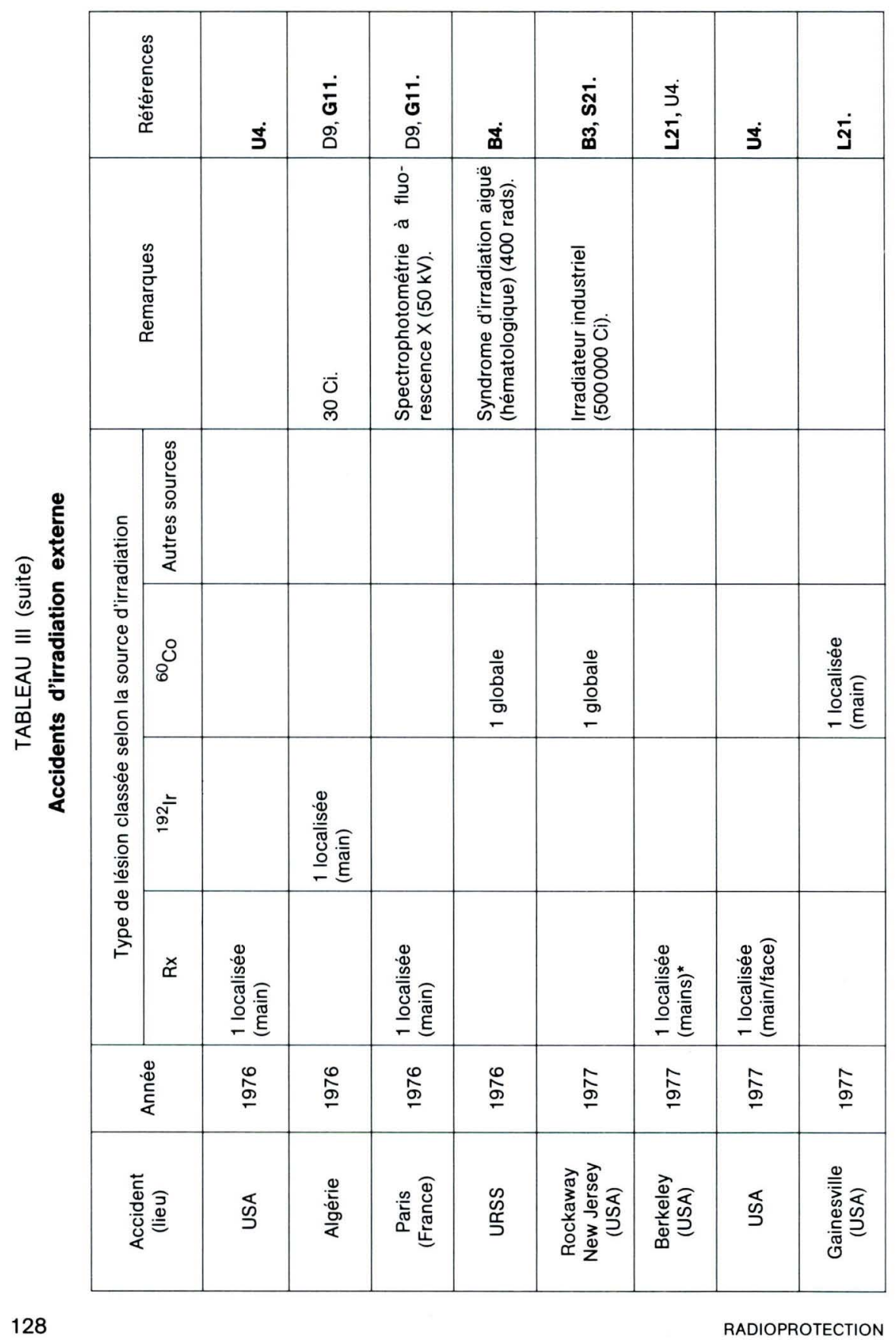


UN REPERTOIRE DES ACCIDENTS RADIOLOGIQUES, 1945-1985

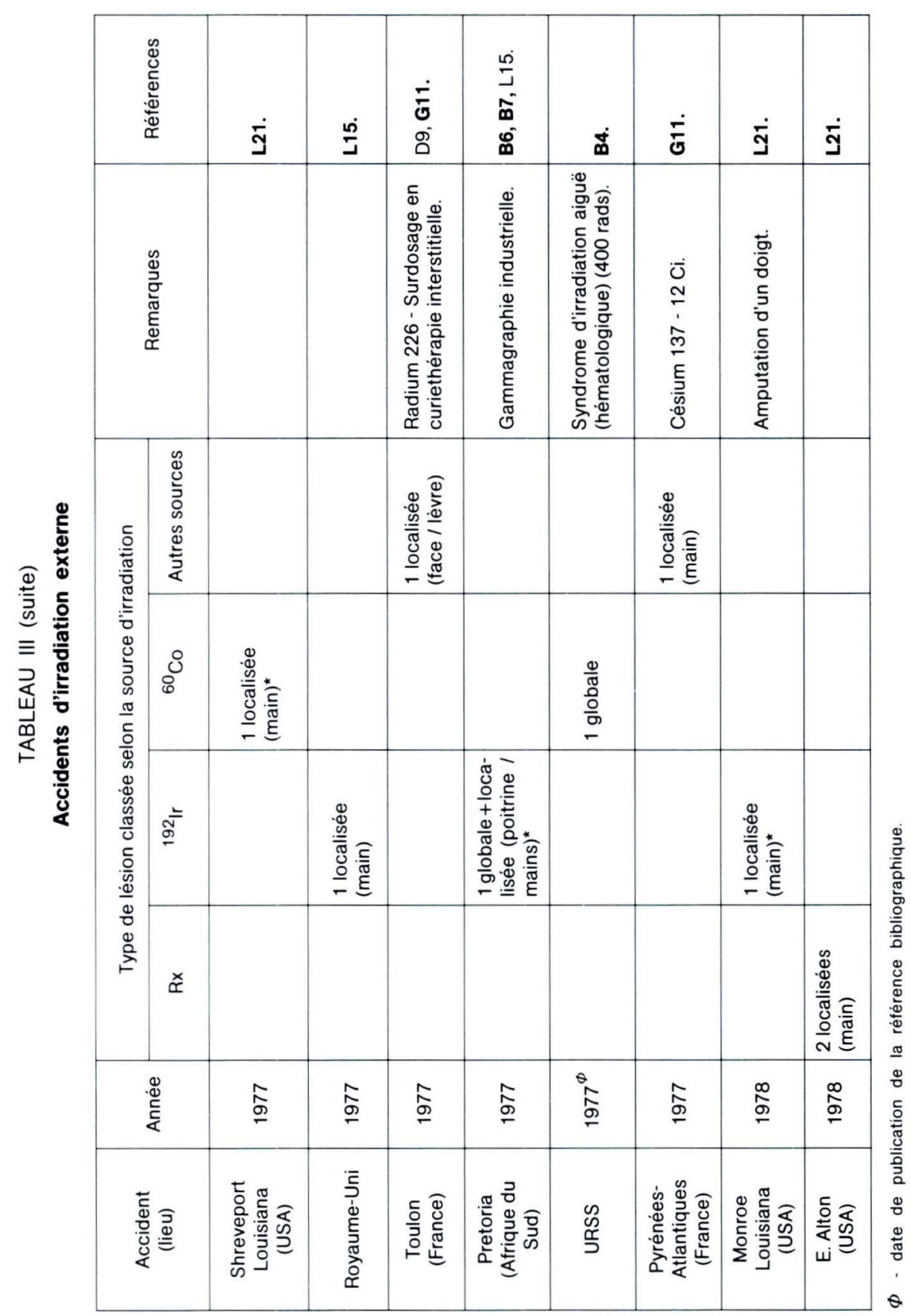

VOL. $22-\mathrm{N}^{\circ} 2$ 
A. RODRIGUES DE OLIVEIRA

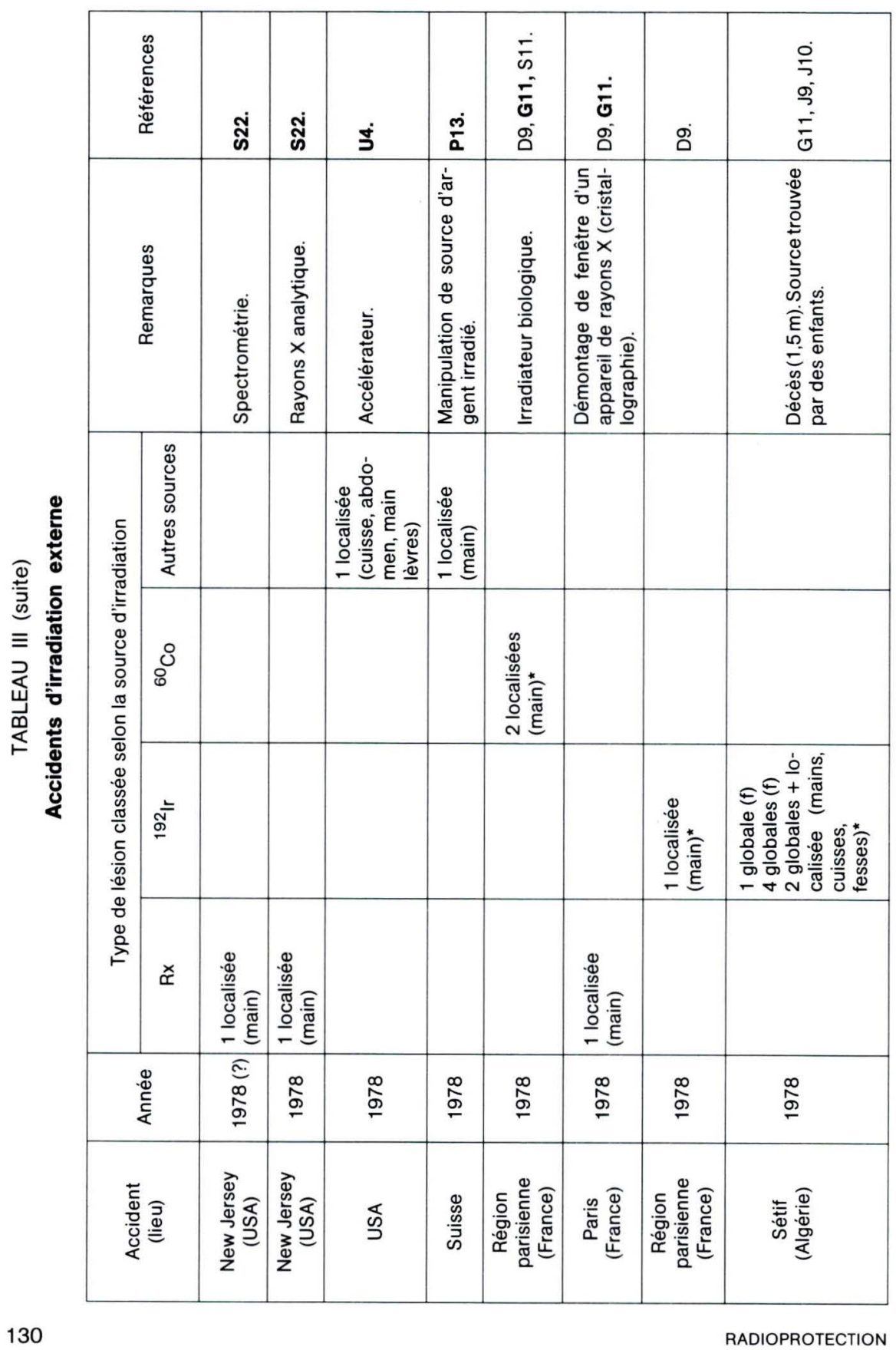


UN RÉPERTOIRE DES ACCIDENTS RADIOLOGIQUES, 1945-1985

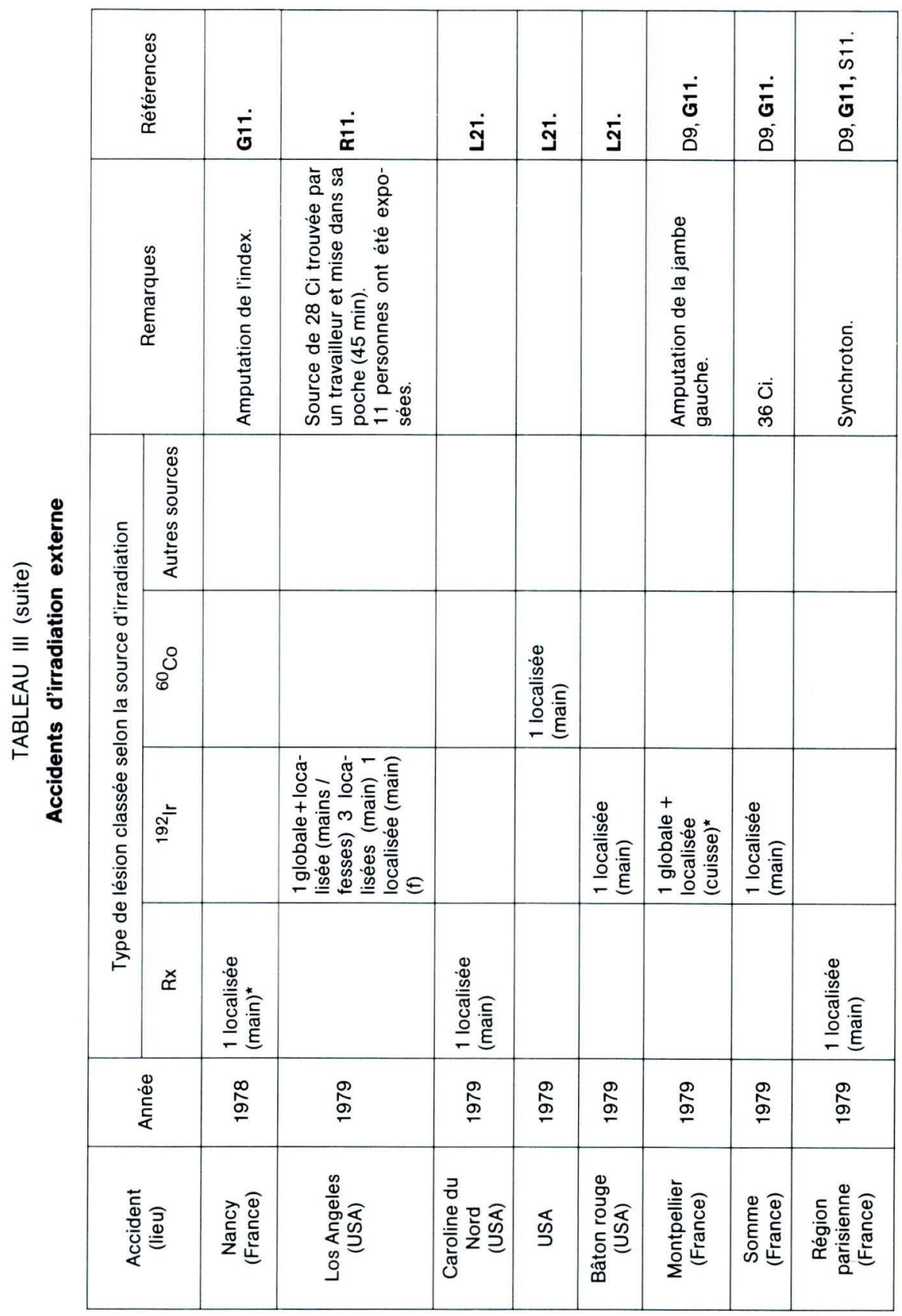

VOL. $22-\mathrm{N}^{\circ} 2$ 
A. RODRIGUES DE OLIVEIRA

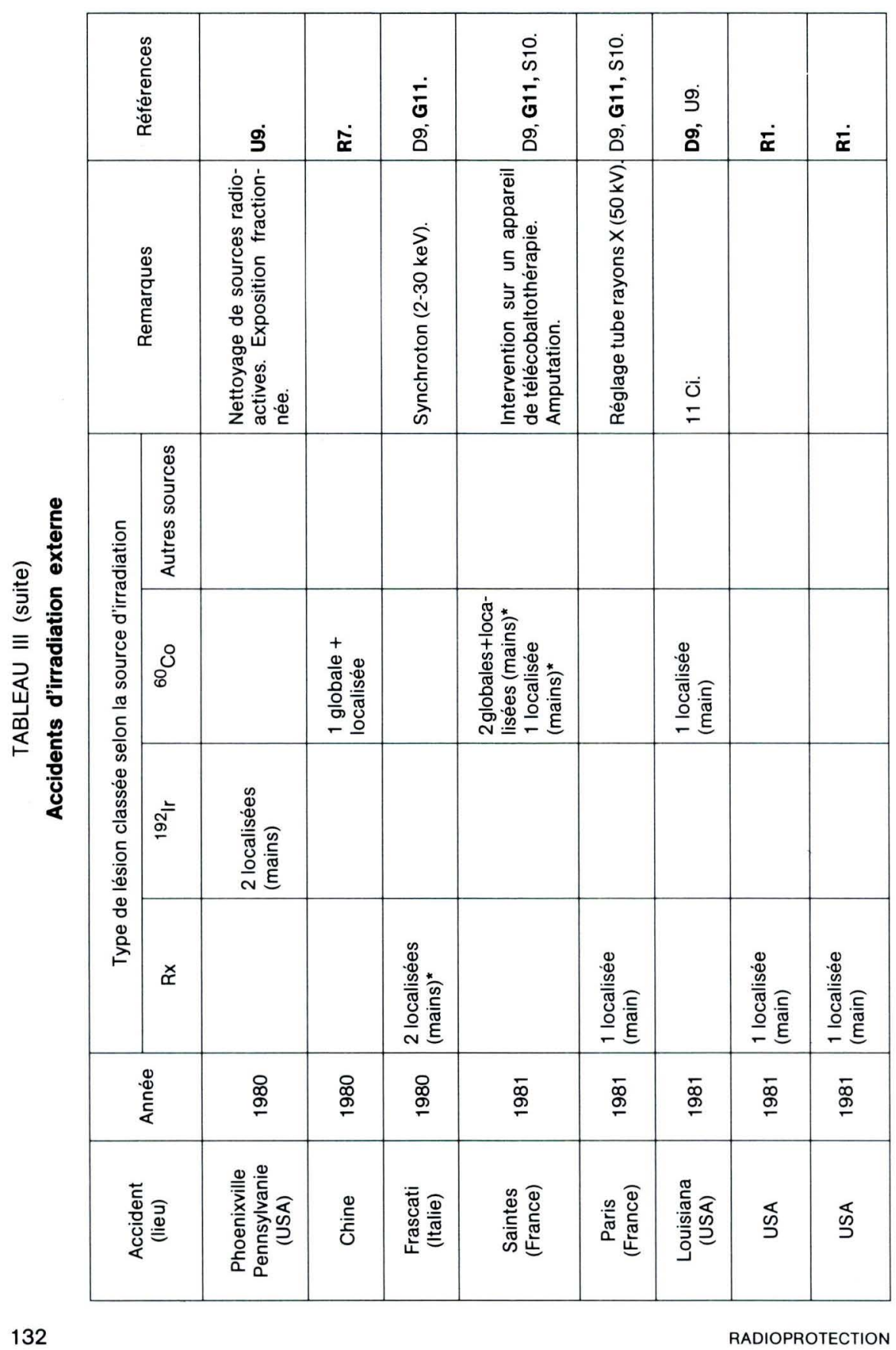


UN REPERTOIRE DES ACCIDENTS RADIOLOGIQUES, 1945-1985

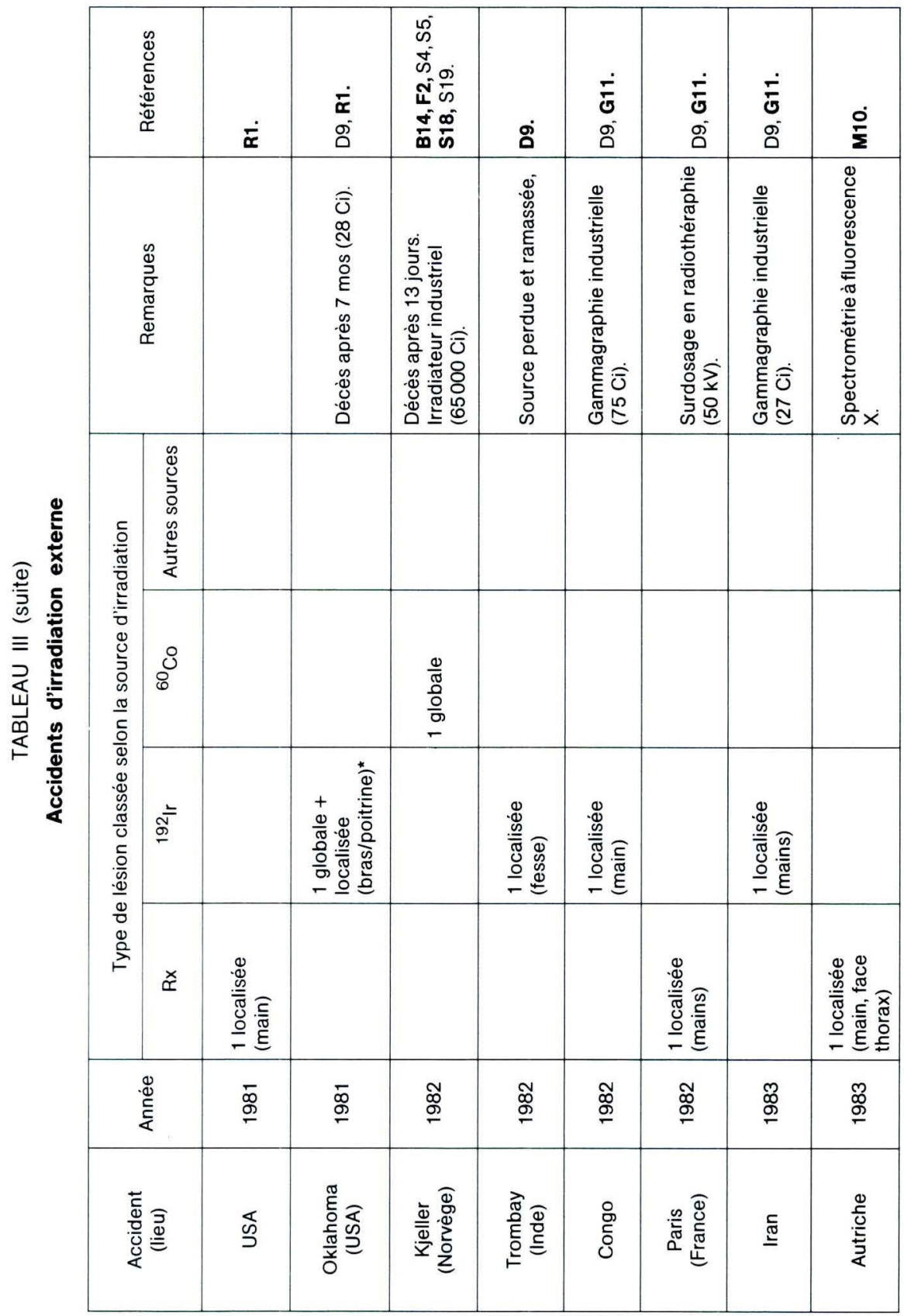


A. RODRIGUES DE OLIVEIRA

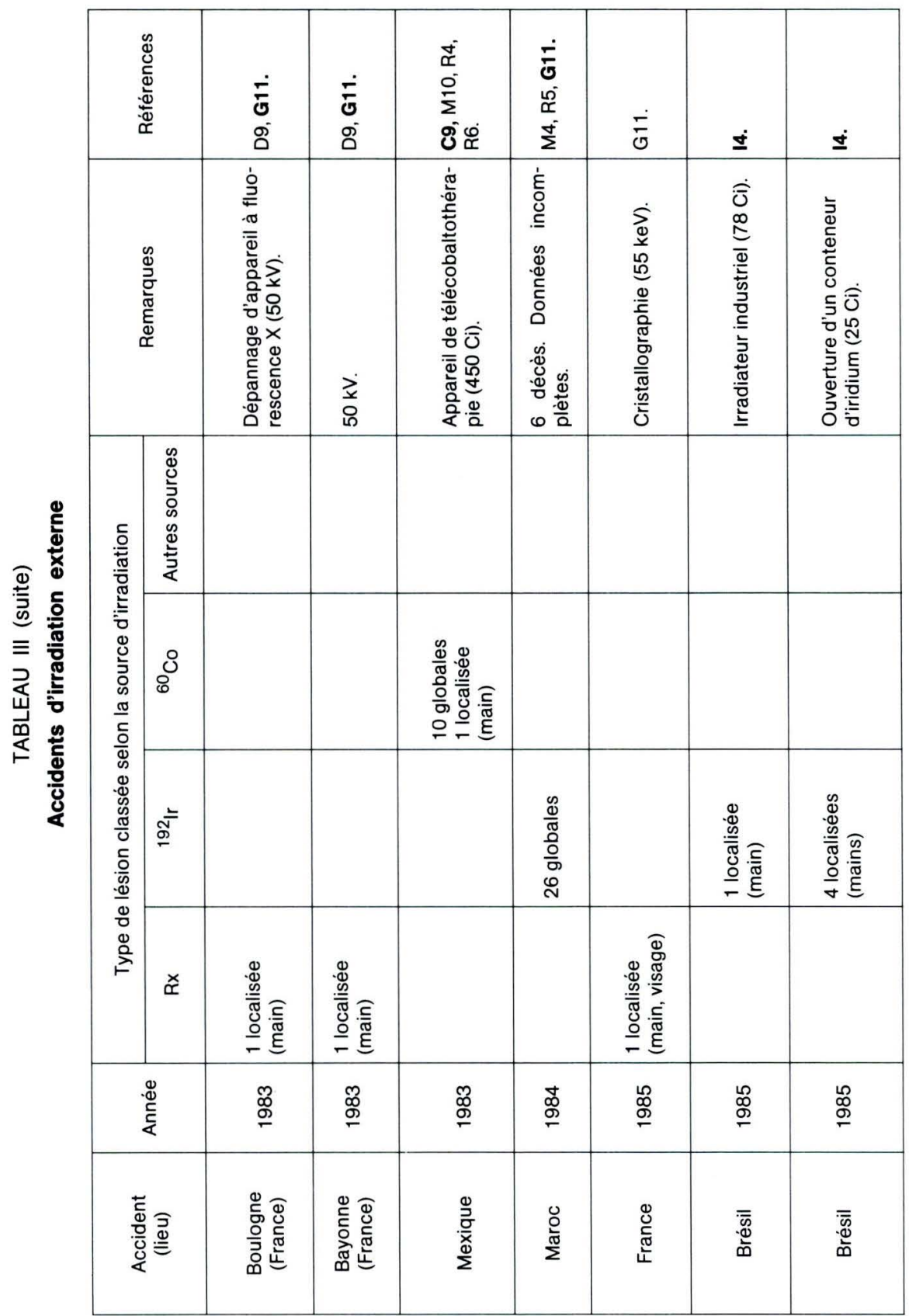


Bilan général des accidents radiologiques survenus pendant la période 1945-1985*

1. Nombre d'événements avec des victimes ............... 178

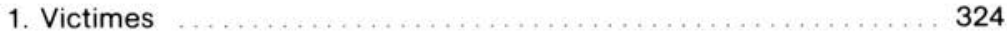

2. Survivants ................................... 297

2.1. des accidents de criticité .....................6 60

2.2. des irradiations globales $\ldots \ldots \ldots \ldots \ldots \ldots \ldots \ldots \ldots \ldots . . \ldots 8$

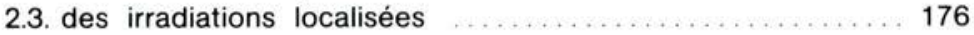

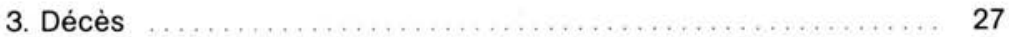

3.1. causés par des accidents de criticité $\ldots \ldots \ldots \ldots \ldots \ldots . . \ldots 9 . \ldots 9$

3.2. causés par les irradiations globales ............... 18

* A l'exclusion des retombées sur les îles Marshall. 